This report was prepared as an account of work sponsored by an agency of the United States Government. Neither the United States Government nor any agency thereof, nor any of their employees, makes any warranty, express or implied, or assumes any legal liability or responsibility for the accuracy, completeness, or usefulness of any information, apparatus, product, or process disclosed, or represents that its use would not infringe privately owned rights. Reference herein to any specific commercial product, process, or service by trade name, trademark, manufacturer, or otherwise does not necessarily constitute or imply its endorsement, recommendation, or favoring by the United States Government or any agency thereof. The views and opinions of authors expressed herein do not necessarily state or reflect those of the United States Government or any agency thereof.

\title{
Vapor Space Characterization of Waste Tank 241-TX-105: Results from Samples Collected on 12/20/94
}

\author{
G. S. Klinger \\ T. W. Clauss \\ M. W. Ligotke \\ K. H. Pool \\ R. B. Lucke \\ B. D. McVeety \\ O. P. Bredt \\ J. S. Young \\ M. McCulloch \\ J. S. Fruchter \\ S. C. Goheen
}

June 1995

Prepared for Westinghouse Hanford Company

under a Related Services Agreement

with the U.S. Department of Energy

Contract DE-AC06-76RLO 1830

Pacific Northwest Laboratory

Richland, Washington 99352 


\section{DISCLAIMER}

Portions of this document may be illegible in electronic image products. Images are produced from the best available original document. 


\section{Summary}

This report describes inorganic and organic analyses results from samples obtained from the headspace of the Hanford waste storage Tank 241-TX-105 (referred to as Tank TX-105). The results described here were obtained to support safety and toxicological evaluations. A summary of the results for inorganic and organic analytes is listed in Table 1. Detailed descriptions of the results appear in the text.

Quantitative results were obtained for the inorganic compounds ammonia $\left(\mathrm{NH}_{3}\right)$, nitrogen dioxide $\left(\mathrm{NO}_{2}\right)$, nitric oxide (NO), and water $\left(\mathrm{H}_{2} \mathrm{O}\right)$. Sampling for hydrogen cyanide $(\mathrm{HCN})$ and sulfur oxides $\left(\mathrm{SO}_{\mathrm{X}}\right)$ was not requested. Trends in $\mathrm{NH}_{3}$ and $\mathrm{H}_{2} \mathrm{O}$ samples indicated a possible minor sampling problem. In addition, quantitative results were obtained for target organic analytes, 39 TO14 compounds, plus an additional 14 analytes. Of these, six were observed above the 5-ppbv reporting cutoff. One organic tentatively identified compound (TIC) was observed above the reporting cutoff of (ca.) $10 \mathrm{ppbv}$, and is reported with a concentration that is a semiquantitative estimate based on internal-standard response factors. All seven organic analytes are listed in Table 1 and account for $100 \%$ of the total organic components in Tank TX-105. One permanent gas, carbon dioxide $\left(\mathrm{CO}_{2}\right)$, was also detected.

Table 1. Summary Results of Inorganic and Organic Samples Collected from the Headspace of Tank TX-105 on 12/20/94

\begin{tabular}{|c|c|c|c|}
\hline Category & Analyte & $\begin{array}{l}\text { Vapor }{ }^{(a)} \\
\text { Concentration }\end{array}$ & Units \\
\hline Inorganic & $\begin{array}{l}\mathrm{NH}_{3} \\
\mathrm{NO}_{2} \\
\mathrm{NO} \\
\mathrm{H}_{2} \mathrm{O}\end{array}$ & $\begin{array}{c}20 \pm 1 \\
\leq 0.02 \\
1.04 \pm 0.10 \\
15.0 \pm 0.9\end{array}$ & $\begin{array}{l}\mathrm{ppmv} \\
. \mathrm{ppmv} \\
\mathrm{ppmv} \\
\mathrm{mg} / \mathrm{L}\end{array}$ \\
\hline Organic & $\begin{array}{l}\text { Acetone } \\
\text { Carbon Tetrachloride } \\
\text { Trichlorofluoromethane } \\
\text { 2-Butanone } \\
\text { Chloroform } \\
\text { Unknown C5 ether } \\
\text { Chloromethane }\end{array}$ & $\begin{array}{l}2.29 \\
2.18 \\
0.38 \\
0.15 \\
0.08 \\
0.05 \\
0.02\end{array}$ & $\begin{array}{l}\mathrm{mg} / \mathrm{m}^{3} \\
\mathrm{mg} / \mathrm{m}^{3} \\
\mathrm{mg} / \mathrm{m}^{3} \\
\mathrm{mg} / \mathrm{m}^{3} \\
\mathrm{mg} / \mathrm{m}^{3} \\
\mathrm{mg} / \mathrm{m}^{3} \\
\mathrm{mg} / \mathrm{m}^{3}\end{array}$ \\
\hline Permanent Gases & $\mathrm{CO}_{2}$ & 156 & ppmv \\
\hline
\end{tabular}

(a) Vapor concentrations were determined using sample-volume data provided by Westinghouse Hanford Company and are based on averaged data. 
•

. 


\section{Acknowledgments}

The authors gratefully acknowledge the support of other project staff at Pacific Northwest Laboratory who contributed to the successful completion of this sampling and analysis activity. Jeff Edwards served as the PNL single-point-of-contact and coordinated sample handling and communications with Westinghouse Hanford Company. K. B. Olsen assisted in preparing the organic portion of this report. Sally Slate, May-Lin Thomas, and Karen Schielke analyzed inorganic samples, and Gary Dennis prepared the solid-sorbent sample trains. Bonnie L. Lehrman provided word processing support. Kurt L. Silvers coordinated the overall report production. 
. 


$\begin{array}{ll}\text { CAS } & \text { Chemical Abstracts Service } \\ \text { COC } & \text { chain of custody } \\ \text { Concentration by volume } \\ \text { DIW } & \begin{array}{l}\text { deionized water } \\ \text { emf }\end{array} \\ \text { electromotive force } \\ \text { EPA } & \text { U.S. Environmental Protection Agency } \\ \text { GC/MS } & \text { gas chromatography/mass spectrometry } \\ \text { GC/TCD } & \text { gas chromatography/thermal conductivity detection } \\ \text { HP } & \text { Hewlett Packard } \\ \text { IC } & \text { ion chromatography } \\ \text { IL } & \text { impact level } \\ \text { IS } & \text { internal standard } \\ \text { MDL } & \text { minimum detection limit } \\ \text { NIST } & \text { National Institute for Standards and Technology } \\ \text { NPH } & \text { normal paraffin hydrocarbon } \\ \text { OSHA } & \text { Occupational Safety and Health Administration } \\ \text { PFA } & \text { perfluoroalkoxy } \\ \text { PNL } & \text { Pacific Northwest Laboratory } \\ \text { ppbv } & \text { part per billion by volume } \\ \text { ppmv } & \text { part per million by volume } \\ \text { QA } & \text { quality assurance } \\ \text { REL } & \text { recommended exposure limit } \\ \text { RPD } & \text { relative percent difference } \\ \text { SCIC } & \text { suppressed-conductivity ion chromatography } \\ \text { SIE } & \text { selective ion electrode } \\ \text { SRM } & \text { standard reference material } \\ \text { STP } & \text { standard temperature and pressure } \\ \text { TEA } & \text { triethanolamine } \\ \text { TIC } & \text { tentatively identified compound } \\ \text { VSS } & \text { vapor sampling system } \\ \text { WHC } & \text { Westinghouse Hanford Company } \\ & \end{array}$




\section{Contents}

Summary $\ldots \ldots \ldots \ldots \ldots \ldots \ldots \ldots \ldots \ldots \ldots \ldots \ldots \ldots \ldots \ldots \ldots \ldots \ldots$ iii

Acknowledgments . . . . . . . . . . . . . . . . . . . . . .

Abbreviations $\ldots \ldots \ldots \ldots \ldots \ldots \ldots \ldots \ldots \ldots \ldots \ldots \ldots \ldots \ldots \ldots \ldots \ldots \ldots$

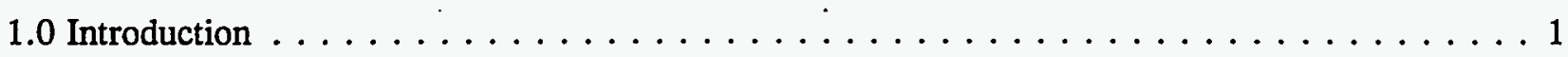

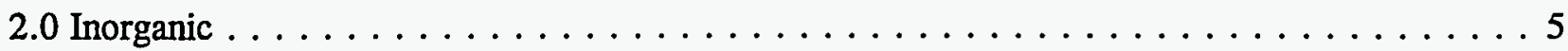

2.1 Standard Sampling Methodology $\ldots \ldots \ldots \ldots \ldots \ldots \ldots \ldots \ldots \ldots \ldots$

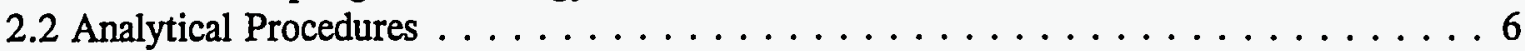

2.3 Quality Assurance/Quality Control $\ldots \ldots \ldots \ldots \ldots \ldots \ldots \ldots \ldots$

2.4 Inorganic Sample Results . . . . . . . . . . . . . . . . 9

3.0 Organic . . . . . . . . . . . . . . . . . . . . 13

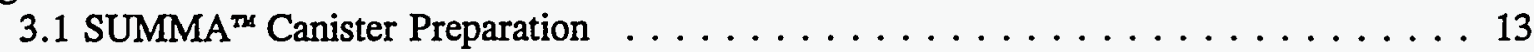

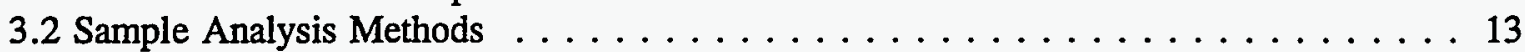

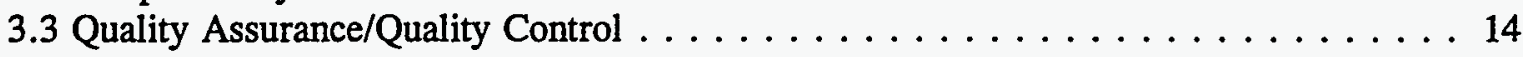

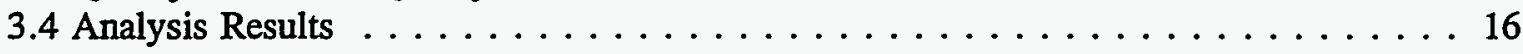

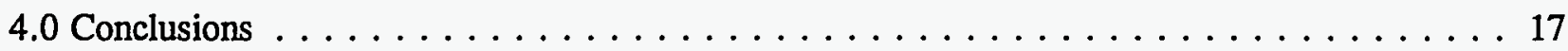

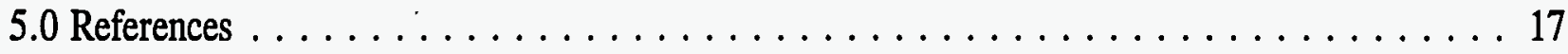

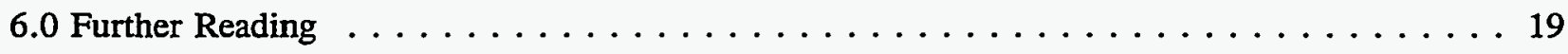

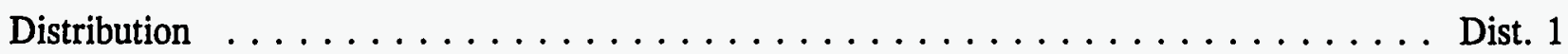




\section{Tables}

2.1 Analysis Procedures and Typical Detection Limits of Target Inorganic Analytes . . . . . 8

2.2 List of PNL Inorganic Samples, Controls, and Gravimetric Results Obtained from a Heated Tube Inserted into the Headspace of Tank TX-105 on $12 / 20 / 94 \ldots \ldots$. . . . . 10

2.3 Inorganic Vapor Sample Results Obtained from a Heated Tube Inserted into the Headspace of Tank TX-105 on $12 / 20 / 94 \ldots \ldots \ldots \ldots \ldots \ldots \ldots$

3.1 Positively Identified and Quanitated Target Organic Analytes of Samples Collected from the Headspace of Tank TX-105 in SUMMA ${ }^{\text {Ts }}$ Canisters on 12/20/94 . . . . . . 20

3.2 Tentatively Identified Compounds and Estimated Concentrations of Samples from the Headspace of Tank TX-105 in SUMMA ${ }^{\text {Th }}$ Canisters Collected on 12/20/94 . . . 22

3.3 Positively Identified and Quantitated Target Organic Analytes of Replicate Analyses of a Single SUMMA ${ }^{\text {TH }}$ Canister Collected from the Headspace of Tank TX-105

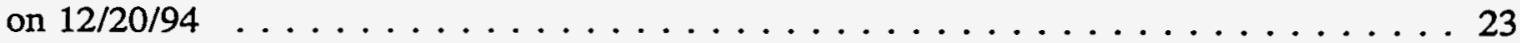

3.4 Tentatively Identified Compounds and Estimated Concentrations of Replicate Analyses of a Single SUMMA ${ }^{\mathrm{nd}}$ Canister Collected from the Headspace of Tank TX-105

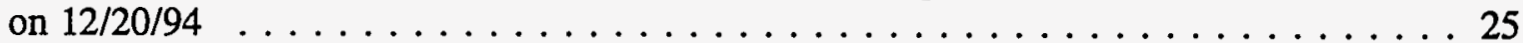

3.5 Positively Identified and Quantitated Target Organic Analytes for Ambient Air Collected Near Tank TX-105 in a SUMMA ${ }^{\text {Ts }}$ Canister on 12/20/94 . . . . . . . . . 26

3.6 Permanent Gas Analysis Results for Samples Collected from the Headspace of Tank TX-105 and for Ambient Air Samples Collected Near Tank TX-105 in SUMMA $^{\text {Th }}$ Canisters on $12 / 20 / 94$

\section{Figures}

1.1 Chain-of-Custody for Tank $\mathrm{TX}-105 \ldots \ldots \ldots \ldots \ldots \ldots \ldots$

3.1 Total Ion Chromatogram for Hanford Waste Tank TX-105 SUMMA ${ }^{\text {Th }}$ Canister Sample S4087-A08.153 Collected on $12 / 20 / 94 \ldots \ldots \ldots \ldots$. . . . . . . . . . . 28 


\subsection{Introduction}

This report describes results of the analyses of tank-headspace samples taken from the Hanford waste Tank 241-TX-105 (referred to as Tank TX-105). Pacific Northwest Laboratory $(\mathrm{PNL})^{(a)}$ contracted with Westinghouse Hanford Company (WHC) to provide sampling devices and to analyze inorganic and organic analytes collected from the tank headspace and ambient air near the tank. The target organic analytes for TO-14 compounds were extended to include 14 analytes identified by the Toxicological Review Panel for Tank C-103 and reported by Mahlum et al. (1994). Program management included these analytes for future tank analyses as identified in the fiscal year work plan. This plan is attached to a letter dated 9/30/94 and addressed to Mr. T. J. Kelly of WHC. The plan also requires PNL to analyze for the permanent gases as shown in Table 3.6. The sample job was designated S4087, and samples were collected by WHC on December 20,1994, using the vapor sampling system (VSS). The results of the analyses are expected to be used to estimate the potential toxicity of tank-headspace gas as described in Data Quality Objectives for Generic In-Tank Health and Safety Vapor Issue Resolution, WHC-SD-WM-DQO-002, Rev. 0.

Sampling devices, including six sorbent trains (for inorganic analyses), and eight SUMMA ${ }^{\text {nu }}$ canisters (for organic analyses) were supplied to the WHC sampling staff on December 12. Samples were taken (by WHC) from the tank headspace on December 20 and were returned to PNL from the field on January 5, 1995. Inorganic (sorbent trap) samples were delivered to PNL on chain of custody (COC) 008087 (see Figure 1.1a). The SUMMA ${ }^{\text {Ts }}$ canisters were delivered on COC 008086 (see Figure 1.1b).

The samples were inspected upon delivery to the 326/23B laboratory and logged into PNL record book 55408 as described in PNL Technical Procedure PNL-TVP-07(b). Custody of the sorbent traps was transferred to PNL personnel performing the inorganic analysis and stored at refrigerated $\left(\leq 10^{\circ} \mathrm{C}\right)$ temperature until the time of analysis. The canister was stored in the 326/23B laboratory at ambient $\left(25^{\circ} \mathrm{C}\right)$ temperature until time of analysis. Access to the 326/23B laboratory is limited to PNL personnel working on the waste-tank safety program. Analyses described in this report were performed at PNL in the $\mathbf{3 0 0}$ area of the Hanford Reservation. Analytical methods that were used are described in the text. In summary, sorbent traps for inorganic analyses containing sample materials were either weighed (for water analysis) or weighed and desorbed with the appropriate aqueous solutions (for ammonia, nitrogen dioxide, and nitric oxide analyses). The aqueous extracts were analyzed by either selective electrode or ion chromatography (IC). Organic analyses were performed using cryogenic preconcentration followed by gas chromatography/mass spectrometry (GC/MS). Permanent gas analysis was performed using a gas chromatography/thermal conductivity detector (GC/TCD).

\footnotetext{
(a) Pacific Northwest Laboratory is operated for the U. S. Department of Energy by Battelle Memorial Institute under Contract DE-AC06-76RLO 1830.

(b) PNL-TVP-07, Rev. 0, October 1994, Sample Shipping and Receiving Procedure for PNL Waste Tank Samples, PNLTechnical Procedure, Tank Vapor Project, Richland, Washington.
} 


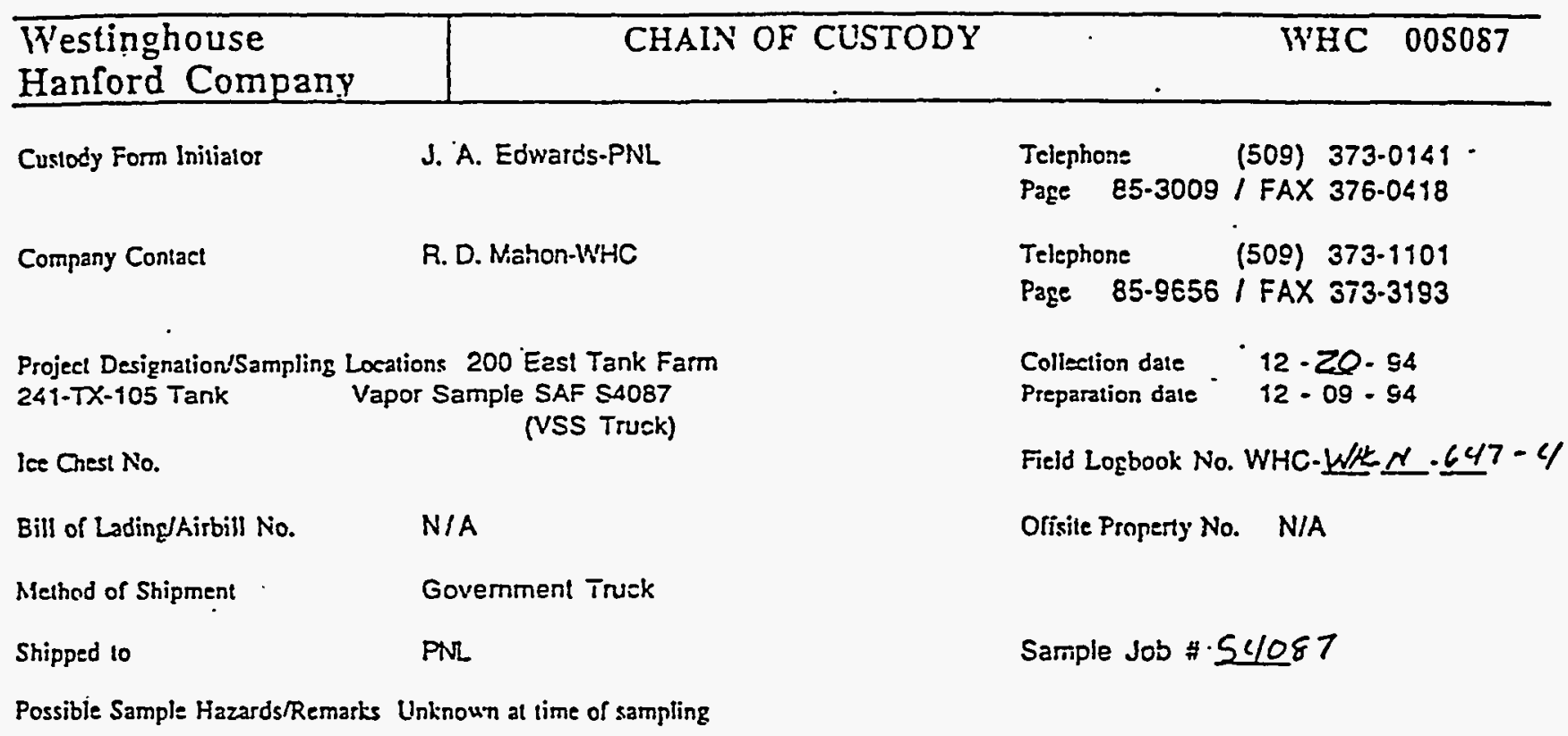

Sample loentificstion

\begin{tabular}{|c|c|c|}
\hline$S 4087^{-A 26} \cdot \mathrm{V} 18^{\circ}$ & $\mathrm{NH}{ }_{3} / \mathrm{NO}_{x} / \mathrm{H}_{2} \mathrm{O}(\operatorname{Trap} \# 1)$ & Line $\# 9$ \\
\hline S4087-A27.V19. & $\mathrm{NH}_{3} / \mathrm{NO}_{4} / \mathrm{H}_{2} \mathrm{O}(\mathrm{Trap} \# 2)$ & Line $\# 10$ \\
\hline $54087-A 28 \cdot V 20^{\circ}$ & $\mathrm{NH}_{3} / \mathrm{NO}_{x} / \mathrm{H}_{z} \mathrm{O}($ Trap $\#$ 3) & Line $\stackrel{\|}{\pi} 8$ \\
\hline $54087-A 29 . V 21$. & $\mathrm{NH}_{3} / \mathrm{NO}_{x} / \mathrm{H}_{2} \mathrm{O}$ (Trap & Line $\# 10$ \\
\hline$\$ 4087-A 30 . V 22^{\circ}$ & $\mathrm{NH}_{3} / \mathrm{NO}_{2} / \mathrm{H}_{2} \mathrm{O}$ (Trap & Line \# 9 \\
\hline $54087-A 31 . V 23$ & $\mathrm{NH}_{3} / \mathrm{NO}_{2} / \mathrm{H}_{2} \mathrm{O}$ (Trap \# & Line $\# 10$ \\
\hline
\end{tabular}

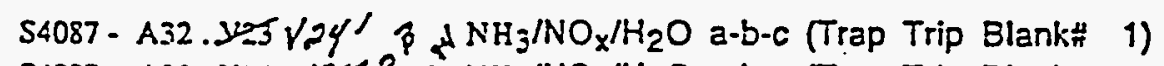

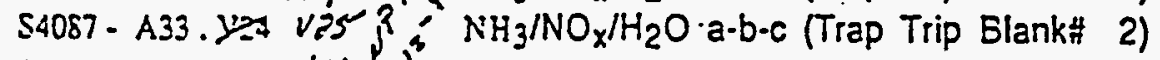

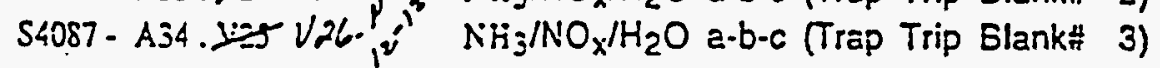

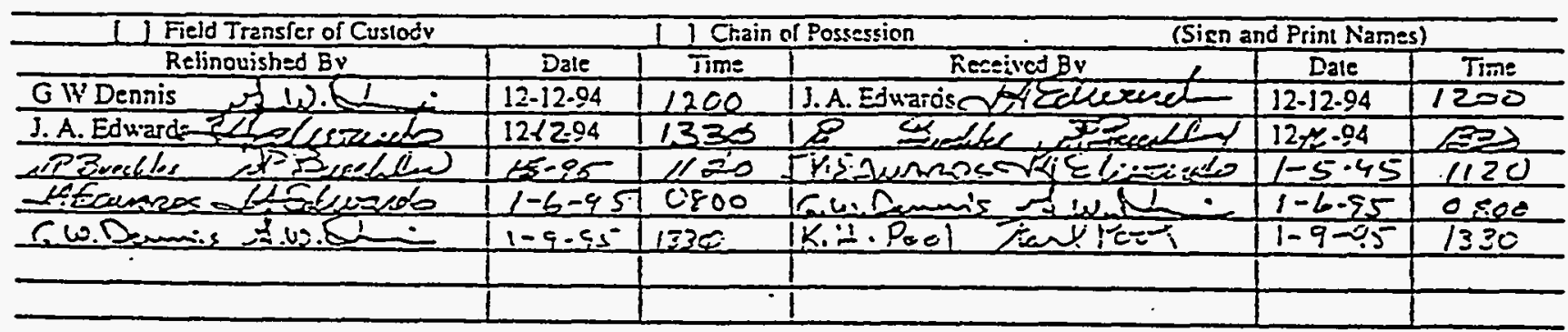

Comments:

Final Sample Disposition

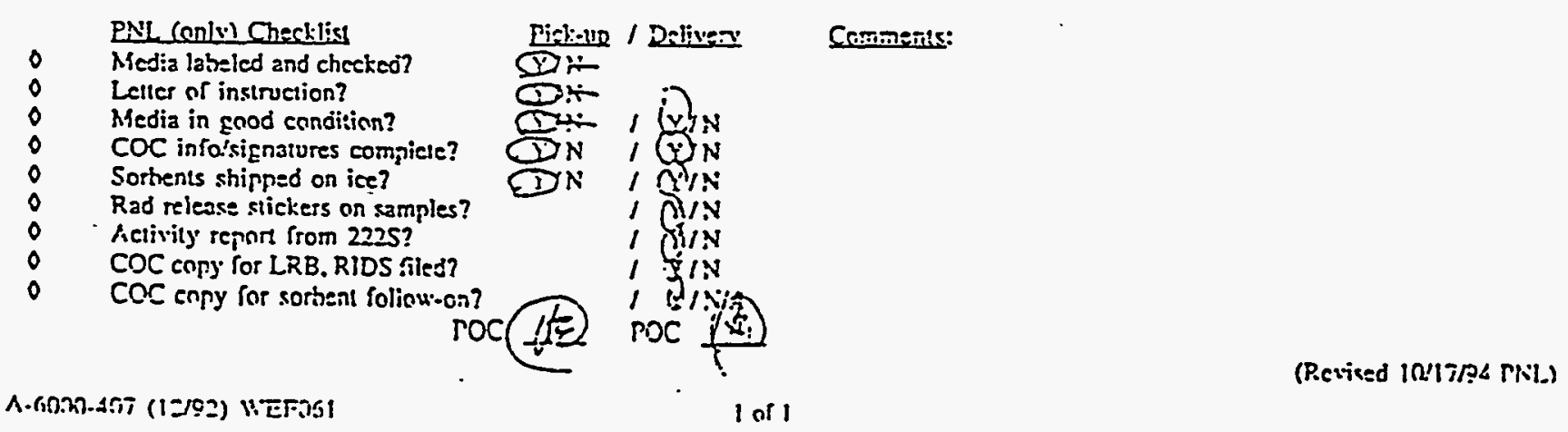

Figure 1.1a Chain-of-Custody for Inorganic Samples 


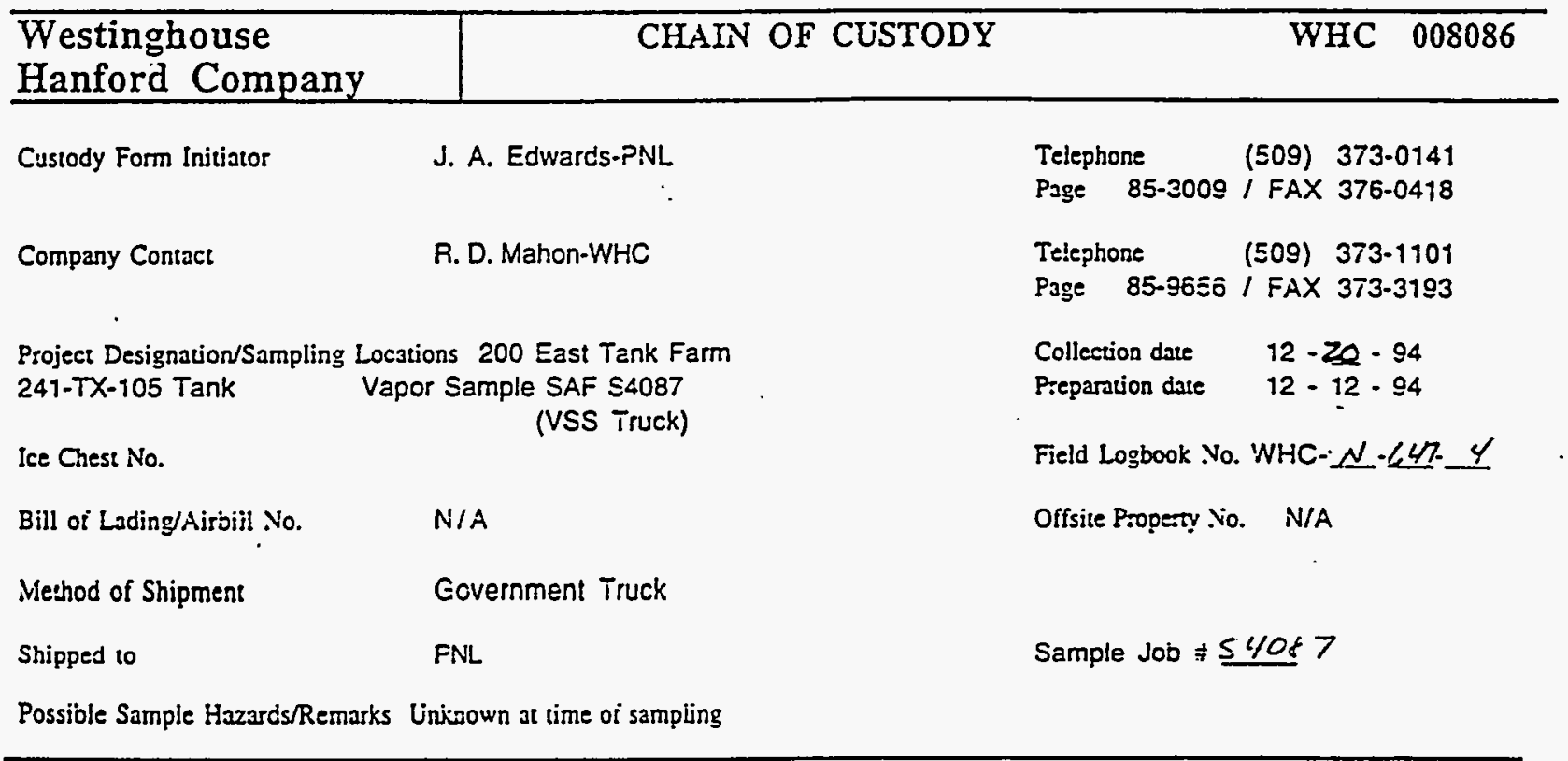

Samnie Icentuicarion

\begin{tabular}{|c|c|c|}
\hline $\begin{array}{l}S \div 087- \pm 01 \cdot 013 \\
S+087-A 02.116\end{array}$ & $\begin{array}{l}\text { Ambient Air SLAQV } \\
\text { Amoient Air SLi.VLL }\end{array}$ & $\begin{array}{l}A=1 \text { Cpwind TY-i05 } \\
\mathrm{A}=2 \text { Througi Por } 15\end{array}$ \\
\hline $\begin{array}{l}S \div 087-A 04 \cdot 120{ }^{\circ} \\
S 4087-.05 .122 . \\
S \div 087-A 06.123 .\end{array}$ & 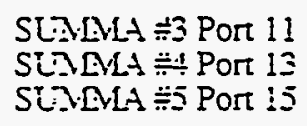 & $\begin{array}{l}\text { (OGD } \\
\text { (OGD) } \\
\text { (OGI) }\end{array}$ \\
\hline $\begin{array}{l}S 4087-A 07.152 \\
S 4087-A 08.153 \\
S 4087-A 00.255\end{array}$ & 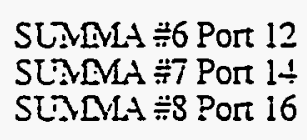 & $\begin{array}{l}\text { (PNIL) } \\
\text { (PNIL) } \\
\text { (PNI) }\end{array}$ \\
\hline
\end{tabular}

\begin{tabular}{|c|c|c|c|c|c|}
\hline I I Field Transie of Custody & & I I Chain & of Possession & ana P:int Yames & \\
\hline Relinopished BV & Dale & Tinse & Recs:ved By & \begin{tabular}{|l|l|} 
Dars \\
\end{tabular} & Time \\
\hline J.A. Edwards ZCESereex & $12=12-01$ & 1325 & 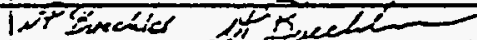 & $112-: 2-94$ & 1325 \\
\hline 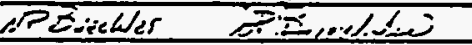 & $x^{2}-<=5-1$ & $1 /=0$ & 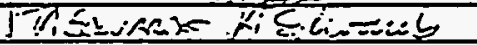 & $11-5-i 5 \mid$ & $11 \geq 2$ \\
\hline & & & I & $1-1$ & \\
\hline & I & & I & $T$ & \\
\hline & L & - & T & 1 & \\
\hline 厂 & & & & f: & \\
\hline & & & & T & \\
\hline
\end{tabular}

Comments:

Final Sampie Disposition

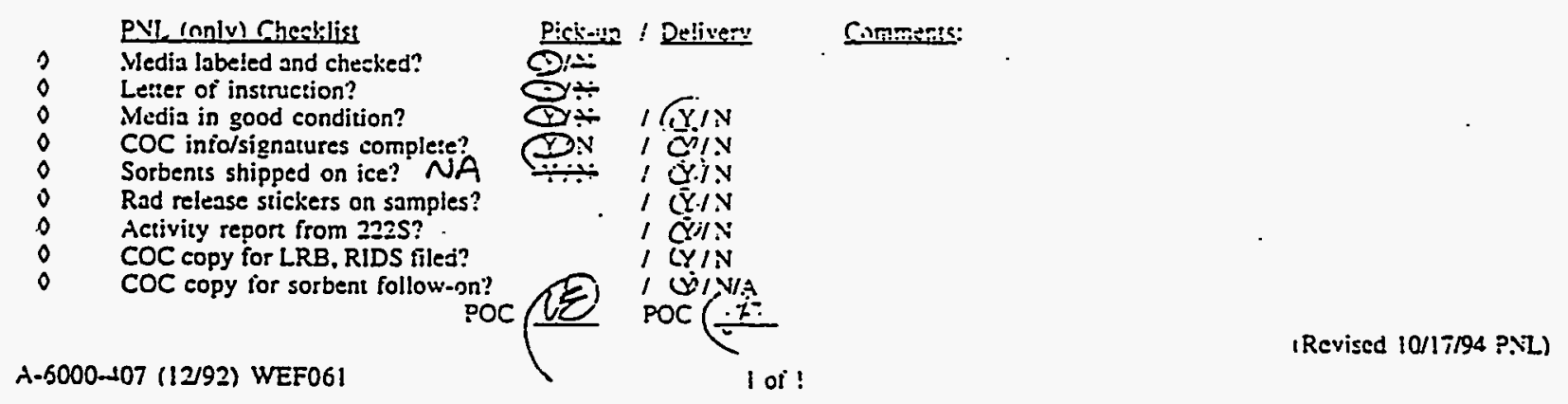

Figure 1.1b Chain-of-Custody for Organic Samples 



\subsection{Inorganic}

Solid sorbent traps, prepared in multi-trap sampling trains, were supplied to WHC for sampling the tank headspace using the VSS. Blanks, spiked blanks (when requested), and exposed samples were returned to PNL for analysis. Analyses were performed to provide information on the tank-headspace concentration of the following analytes: ammonia $\left(\mathrm{NH}_{3}\right)$, nitrogen dioxide $\left(\mathrm{NO}_{2}\right)$, nitric oxide (NO), and water $\left(\mathrm{H}_{2} \mathrm{O}\right)$. Procedures were similar to those developed previously during sample jobs performed with the VSS connected to the headspace of Tank C-103 (Ligotke et al. 1994). During those sample jobs, control samples provided validation that samples were effectively trapping $\mathrm{NH}_{3}$ and mass. Sample preparation, handling and disassembly were performed as described in Technical Procedure PNL-TVP-09(a). Analytical accuracy was estimated based on procedures used. Sample preparation and analyses were performed following PNL quality assurance (QA) impact level (IL) II requirements.

\subsection{Standard Sampling Methodology}

Standard glass tubes containing sorbent materials to trap vapors of selected analytes of $\mathrm{NH}_{3}$, $\mathrm{NO}, \mathrm{NO}_{2}$, and $\mathrm{H}_{2} \mathrm{O}$ (SKC Inc., Eighty Four, Pennsylvania) were obtained, prepared, and submitted for use by WHC. The sorbent traps were selected based on their use by the Occupational Safety and Health Administration (OSHA) to perform workplace monitoring, and because of available procedures and verification results associated with that particular application. The typical sorbent traps used consisted of a glass tube containing a sorbent material specific to the compound of interest. In general, the tubes contained two sorbent layers, or sections; the first layer was the primary trap, and the second layer provided an indication of breakthrough. In the tubes, sorbent layers are generally held in packed layers separated by glass wool. The sorbent traps, having glass-sealed ends, were received from the vendor.

The type and nominal quantity of sorbent material varied by application. Sorbent traps were selected for the tank sample job and included the following products. The $\mathrm{NH}_{3}$ sorbent traps contained carbon beads impregnated with sulfuric acid; nominally, $500 \mathrm{mg}$ were contained in the primary and $250 \mathrm{mg}$ in the breakthrough sections. The $\mathrm{NH}_{3}$ was chemisorbed as ammonium sulfate $\left\{\left(\mathrm{NH}_{4}\right)_{2} \mathrm{SO}_{4}\right\}$. The $\mathrm{NO}_{2}$ traps contained a zeolite impregnated with triethanolamine (TEA), with $400 \mathrm{mg}$ in the primary and $200 \mathrm{mg}$ in the breakthrough sections. The $\mathrm{NO}_{2}$ was absorbed and disproportionated to equi-molar quantities of nitrite ions $\left(\mathrm{NO}_{2}{ }^{-}\right)$and nitrate ions $\left(\mathrm{NO}_{3}{ }^{-}\right)$. Glass tubes containing $800 \mathrm{mg}$ of an oxidant such as chromate were used to convert $\mathrm{NO}$ to $\mathrm{NO}_{2}$. The converted NO was then collected as nitrite and nitrate in an $\mathrm{NO}_{2}$ trap. The water traps contained $300 \mathrm{mg}$ of silica gel in the primary and $150 \mathrm{mg}$ in the breakthrough sections.

Samples provided by PNL to trap inorganic compounds include all or some of the following: samples, spiked samples, spares, single trap blanks, and spiked blanks. The samples of each were prepared from same-lot batches, with the oxidizer sections of the $\mathrm{NO}_{\mathrm{x}}$ sorbent trains having been stored previously in a freezer. After sample preparation, all samples, spiked samples, blanks, and spiked blanks were stored in a freezer, primarily because of handling recommendations for the oxidizer tubes attached to some samples. After receipt of exposed and radiologically cleared samples

(a) Pacific Northwest Laboratory. 10/94. Sorbent Trap Preparation for sampling and Analysis: Waste Tank Inorganic Vapor Samples, PNL-TVP-09 (Rev.0), PNL Technical Procedure, Richland, Washington. 
from WHC and disassembly of the sorbent trains, samples were provided to the analytical laboratory at ambient temperature, and selected oxidizer sections were returned to a freezer until completion of analyses.

The sorbent traps were prepared in multi-trap sorbent trains configured so sample flow passed in order through the traps, targeting specific analytes, and then through a desiccant trap. The specific order of traps within the various sorbent trains is described in Section 2.4. The ends of the glass-tube traps were broken, and the traps were weighed and then connected to each other using uniform lengths of 3/8-in. perfluoroalkoxy (PFA)-grade Teflon ${ }^{\circledR}$ tubing. The tubing was heated in hot air and forced over the open ends of the traps to form a tight seal. The inlets of the sorbent trains each consist of a short section of tubing having a 3/8-in. stainless steel Swagelok ${ }^{\oplus}$ nut, sealed using a Swagelok ${ }^{\circledast}$ cap. The trailing ends of the sorbent trains (the downstream end of the traps containing silica gel) were each sealed with red-plastic end caps provided by the manufacturer. The sorbent-trap trains remained sealed other than during the actual sampling periods. C-Flex ${ }^{\circledR}$ tubing was provided by WHC to connect the downstream ends of the sorbent trains to the sampling exhaust manifold connections.

2.1.1 Concentration Calculations. The concentrations of target compounds in the tank headspace were determined from sample results, assuming effective sample transport to the sorbent traps. Concentration, in parts per million by volume (ppmv), was determined by dividing the mass of the compound, in $\mu \mathrm{mol}$, by the volume of the dried tank air sampled in mol. The micromolar sample mass was determined by dividing the compound mass, in $\mu \mathrm{g}$, by the molecular weight of the compound, in $\mathrm{g} / \mathrm{mol}$. The molar sample volume was determined, excluding water vapor, by dividing the standard sample volume (at $0^{\circ} \mathrm{C}$ and 760 torr), in $\mathrm{L}$, by $22.4 \mathrm{~L} / \mathrm{mol}$. For example, the concentration $\left(C_{v}\right)$ of a 3.00-L sample containing $75.0 \mu \mathrm{g}$ of $\mathrm{NH}_{3}$ equals

$$
\mathrm{C}_{\mathrm{v}}=\frac{75.0 \mu \mathrm{g}}{17 \mathrm{~g} / \mathrm{mol}}\left(\frac{3.00 \mathrm{~L}}{22.4 \mathrm{~L} / \mathrm{mol}}\right)^{-1}=32.9 \mathrm{ppmv}
$$

This calculational method produces concentration results that are slightly conservative (greater than actual) because the volume of water vapor in the sample stream is neglected. The volume of water vapor is not included in the measured sampled volume because of its removal in desiccant traps upstream of the mass flowmeter. However, the bias is generally expected to be small. For a tankheadspace temperature of $35^{\circ} \mathrm{C}$, the magnitude of the bias would be about 1 to $6 \%$, assuming tankheadspace relative humidities of 20 to $100 \%$, respectively. The concentration of mass (determined gravimetrically) was also per dry-gas volume at standard conditions.

\subsection{Analytical Procedures}

The compounds of interest were trapped using solid sorbents and chemisorption (adsorption of water vapor). Analytical results were based on extraction and analysis of selected ions. Analytical procedures used are specified in the text. All were compiled in PNL-MA-599.

2.2.1 Ammonia Analysis. The sorbent material from the $\mathrm{NH}_{3}$-selective sorbent traps was placed into labeled 20 -mL glass scintillation vials. Vials containing front-, or primary-, section sorbent material were treated with $10.0 \mathrm{~mL}$ of deionized water (DIW), and vials containing back-up-section 
sorbent material were treated with $5.0 \mathrm{~mL}$ of $\mathrm{DIW}$. After extraction, the $\mathrm{NH}_{3}$ sorbent traps were analyzed using the selective ion electrode (SIE) procedure PNL-ALO-226 Ammonia (Nitrogen) in Aqueous Samples\}. Briefly, this method includes 1) preparing a $1000-\mu \mathrm{g} / \mathrm{mL}$ (ppm) $\mathrm{NH}_{3}$ stock standard solution from dried reagent-grade $\mathrm{NH}_{4} \mathrm{Cl}$ and $\mathrm{DIW}$ on the day analyses are performed; 2) preparing $0.1-, 0.5-, 1.0-, 10-$, and $100-\mathrm{ppm} \mathrm{NH}_{3}$ working calibration standards by serial dilution of the freshly made stock standard; 3) generating an initial calibration curve from the measured electromotive force (emf) signal versus $\mathrm{NH}_{3}$ concentration data obtained for the set of working standards; 4) performing a calibration-verification check, using one of the midrange standards, after analyzing every four or five samples; 5 ) continuing this sequence until all samples of the batch have been measured, including duplicates and spiked samples; and 6) remeasuring the complete set of calibration standards (at the end of the session). Emf signal measurements obtained for samples are compared to those for standards, either graphically or algebraically (using linear regression) to determine $\mathrm{NH}_{3}$ concentration in the samples.

2.2.2 Nitrite Analysis. The sorbent traps for $\mathrm{NO}_{2}$ and $\mathrm{NO}$ were desorbed in an aqueous TEA and n-butanol solution and analyzed by suppressed-conductivity ion chromatography (SCIC) for nitrite according to PNL-ALO-212, Rev. 1 (Determination of Inorganic Anions by Ion Chromatography) modified to obviate interferences by concentrations of non-target analytes. Specifically, the modifications used were 1) eluent $1.44 \mathrm{mM} \mathrm{Na}_{2} \mathrm{CO}_{3}+1.8 \mathrm{mM} \mathrm{NaHCO}$ at $2.0 \mathrm{~mL} / \mathrm{min}$, 2) one guard column (AG4A) and two separator columns (AS4A) in series instead of just one separator column, and 3) all standards, samples, and blanks injected into the IC sample loop through $0.45-\mu \mathrm{m}$ syringe filters.

For the analysis, the sorbent materials were placed into labeled $20-\mathrm{mL}$ glass scintillation vials. To each vial, $3.0 \mathrm{~mL}$ of desorbing solution (15 $\mathrm{g}$ TEA $+1 \mathrm{~mL}$-butanol in $1.0 \mathrm{~L} \mathrm{DIW})$ was added. Primary sorbent-tube sample materials and back-up (breakthrough) sorbent-trap materials were analyzed separately using identical procedures. Each analytical session was conducted as follows. Working nitrite standards $(0,0.1,0.25$, and $0.5 \mathrm{ppm})$ were prepared by diluting a stock nitrite standard with desorbing solution. An initial calibration curve was prepared from the instrument response (chromatographic peak height) versus nitrite standard concentration data for the set of working standards. A calibration verification check using one of the midrange standards was performed after the analysis of every six samples. If the instrument response indicated that sample nitrite concentration was outside the calibration range ( $>0.5 \mathrm{ppm}$ nitrite), the sample was diluted with desorbing solution and reanalyzed. After all samples of a batch were analyzed, the complete set of calibration standards was remeasured to verify consistent instrument response, and the analytical session was terminated.

Instrument responses (peak height) observed for samples were compared to those for standards to determine the nitrite concentration of the samples. Because $\mathrm{NO}_{2}$ and $\mathrm{NO}$ converted to $\mathrm{NO}_{2}$ were collected on the sorbent as equal quantities of nitrite and nitrate, and the analysis was specific for nitrite, the molar masses of $\mathrm{NO}_{2}$ and $\mathrm{NO}$ were determined by doubling the analytically determined molar mass of nitrite.

2.2.3 Mass (Water) Analysis. Sorbent traps used to make each sample train were weighed using a semi-micro mass balance, after labeling and breaking the glass tube ends, without plastic end caps. After receipt of exposed samples, the sorbent traps were again weighed to determine the change in mass. Records of the measurements were documented on sample-preparation data sheets. The mass concentration, generally roughly equal to the concentration of water, was determined by dividing the 
combined change in mass from all traps in a sorbent train by the actual volume of gas sampled. Blanks and spiked blanks were included to provide information on uncertainty.

\subsection{Quality Assurance/Quality Control}

Analytical work was performed according to quality levels identified in the project QA plan and several PNL documents. The samples were analyzed following PNL IL II. The PNL documents include PNL-MA-70 (Part 2), PNL-MA-599, PNL-ALO-212, PNL-ALO-226, and MCS-033. A summary of the analysis procedures and limits for the target inorganic compounds is provided in Table 2.1. From the table, it can be seen that the minimum detection limit (MDL) required to resolve the analyte at one-tenth of the recommended exposure limit (REL) for each of the target analytes is achieved using current procedures and with a vapor-sample volume of $3 \mathrm{~L}$ and a desorption-solution volume of $3 \mathrm{~mL}\left(10 \mathrm{~mL}\right.$ for $\left.\mathrm{NH}_{3}\right)$.

Table 2.1 Analysis Procedures and Typical Detection Limits of Target Inorganic Analytes.

\begin{tabular}{|c|c|c|c|c|c|}
\hline Analyte & Formula & Procedure & $\begin{array}{l}\mathrm{REL}^{(a)} \\
\text { (ppmv) }\end{array}$ & $\begin{array}{l}0.1 \times \mathrm{REL}^{(\mathrm{a})} \\
\text { (ppmv) }\end{array}$ & $\begin{array}{l}\mathrm{MDL}^{(\mathrm{b})} \\
\text { (ppmv) }\end{array}$ \\
\hline Ammonia & $\mathrm{NH}_{3}$ & PNL-ALO-226 & 25 & 2.5 & 0.5 \\
\hline Nitrogen Dioxide & $\mathrm{NO}_{2}$ & PNL-ALO-212 & 1 & 0.1 & 0.02 \\
\hline Nitric oxide & NO & PNL-ALO-212 & 25 & 2.5 & 0.02 \\
\hline Mass (water) ${ }^{(c)}$ & $\mathrm{n} / \mathrm{a}$ & $\mathrm{n} / \mathrm{a}$ & $\mathrm{n} / \mathrm{a}$ & $\mathrm{n} / \mathrm{a}$ & $\mathrm{n} / \mathrm{a}$ \\
\hline
\end{tabular}

(a) Target analytical limits are equal to one-tenth of the REL.

(b) MDL is defined as the vapor concentration that can be detected with an uncertainty equal to about the magnitude of the measurement. The uncertainty is expected to reduce to about one-quarter of the magnitude of the measurement at a concentration of four times the MDL. The MDLs were based on the assumption that $3 \mathrm{~L}$ of vapor are sampled; if greater volumes of vapor are sampled, correspondingly smaller MDLs can be achieved. The MDLs were also based on desorbing-solution volumes of $10 \mathrm{~mL}$ for $\mathrm{NH}_{3}$ and $3 \mathrm{~mL}$ for the other analytes.

(c) The vapor-mass concentration, thought to be largely water vapor, is determined gravimetrically.

The accuracy of concentration measurements depends on errors associated with both sampling and analysis. Sampling information, including sample volumes, was provided by WHC; sample volume uncertainty was not provided. The accuracy of analytical results depends on the method used. For $\mathrm{NH}_{3}$ analyses, the accuracy of laboratory measurements by SIE was estimated to be $\pm 5 \%$ relative, independent of concentration at $1 \mu \mathrm{g} / \mathrm{mL}$ or greater levels. The uncertainty includes preparation of standards, purity of the ammonium salt used to prepare standards, potential operator bias, ambient temperature variations, etc. Unfortunately, no known National Institute for Standards and Technology (NIST)-traceable standard reference material (SRM) is available against which to compare working standards. Similarly, no known NIST SRM is available for nitrite analysis (for $\mathrm{NO}_{2}$ and $\mathrm{NO}$ ). Based on experience in comparing nitrite working standards prepared from several different sources and factors mentioned for $\mathrm{NH}_{3}$ above, the estimated maximum bias for samples derived from sampling for $\mathrm{NO}_{2}$ is $\pm 10 \%$, and for samples derived from sampling for NO, it is $\pm 5 \%$ relative. The accuracy of measurements of sample mass is $\pm 0.05 \mathrm{mg}$, or much less than $1 \%$ of the mass changes of most samples, and roughly $10 \%$ or less of the mass change of most blanks. 
The analytical accuracy of measurements of the change in mass of sorbent trains is estimated to be \pm $1 \mathrm{mg}$ per 5-trap sorbent train; this estimate is based largely on preliminary information that unopened field-blank sorbent trains gain $0.3 \pm 0.4 \mathrm{mg}$ per train.

\subsection{Inorganic Sample Results}

Samples were obtained by WHC from the headspace of Tank TX-105 on 12/20/94 using the VSS. The sample job designation number was S4087. Samples were prepared, submitted to WHC, returned to PNL, and then returned and analyzed to provide information on the concentrations of $\mathrm{NH}_{3}, \mathrm{NO}_{2}, \mathrm{NO}$, and mass (largely $\mathrm{H}_{2} \mathrm{O}$ ). Sampling and analysis for hydrogen cyanide (HCN) and sulfur oxides $\left(\mathrm{SO}_{x}\right)$ were not requested. The inorganic samples were received from WHC on 1/6/95; the sample-volume information was received on $1 / 6 / 95$.

A list of samples, sampling information, sample volumes, and gravimetric results is shown in Table 2.2. The types of sample trains used and the order of sorbent traps within each train are also shown in the table. For example, the sorbent train $\mathrm{NH}_{3} / \mathrm{NO}_{\mathrm{x}} / \mathrm{H}_{2} \mathrm{O}$ contained an $\mathrm{NH}_{3}$ trap at the inlet end, an $\mathrm{NO}_{x}$ series in the middle (Section 2.4.2), and a desiccant trap at the outlet end. Analytical mass and concentration results are shown in Table 2.3. Sample volumes were provided by WHC; sample-volume uncertainty was not provided. Tank-headspace concentration results (Table 2.3) are based on this information, and the listed uncertainties equal plus-or-minus one standard deviation of the individual results from each set of samples. Where analytical results from samples were nearly indistinguishable from those of blanks, indicating very low vapor concentrations of the analyte, the concentration results (Table 2.3) are listed as "less than or equal to" a probable maximum value determined by subtracting the average of the blanks less one standard deviation from the average of the samples plus one standard deviation. Results of control samples, such as spiked blanks, are discussed in this section. Spiked blanks, when used, were transported to the field but not opened. Spiked samples, when used, were opened in the field and used to collect tank vapors. Sample results were not corrected for the percentage recoveries of spiked blanks.

2.4.1 Ammonia Results. The concentration of $\mathrm{NH}_{3}$ was $20 \pm 1$ ppmv, based on all six samples. The $\mathrm{NH}_{3}$ quantities in the sorbent traps ranged from 2.5 to $2.8 \mu \mathrm{mol}$ in the front sorbent sections and about $\leq 0.04 \mu \mathrm{mol}$ in back sorbent sections. Blank corrections, $\leq 0.06 \mu \mathrm{mol}$ in front and back sections, were less than $2.5 \%$ of collected quantities and were neglected. Although spiked blanks were not tested, the percentage recoveries of three sets of blanks spiked with $12.2,22.3$, and 46.4 $\mu \mathrm{mol}$ of $\mathrm{NH}_{3}$ were $101 \pm 4 \%, 109 \pm 2 \%$, and $104 \pm 1 \%$, respectively, during related sample jobs (Clauss et al. 1994; Ligotke et al. 1994). The analysis of one sample was duplicated and yielded a repeatability of less than $\pm 1 \%$. One sample leachate was spiked after initial analysis with roughly the quantity of $\mathrm{NH}_{3}$ in the sample and yielded a percentage recovery of $94 \%$. A 5-point calibration was performed over an $\mathrm{NH}_{3}$ range of 0.1 to $1000 \mu \mathrm{g} / \mathrm{mL}$.

2.4.2 Nitrogen Oxides Results. Measurements of $\mathrm{NO}_{2}$ and $\mathrm{NO}$ were made using six 5-segment $\mathrm{NH}_{3} / \mathrm{NO}_{\mathrm{x}} / \mathrm{H}_{2} \mathrm{O}$ sorbent-trap trains (the $\mathrm{NO}_{\mathrm{x}}$ trains consisted of $\mathrm{NO}_{2}$ trap, oxidizer, and $\mathrm{NO}_{2}$ trap). Related sample jobs, performed using the VSS in Tanks BY-104, -105 , and -106 both with and without $\mathrm{NO}_{\mathrm{x}}$ trains protected by a leading $\mathrm{NH}_{3}$ trap (e.g., Clauss et al. 1994), indicated that the 
Table 2.2 List of PNL Inorganic Samples, Controls, and Gravimetric Results Obtained from a Heated Tube Inserted into the Headspace of Tank TX-105 on 12/20/94

\begin{tabular}{|c|c|c|c|c|c|c|}
\hline \multirow[b]{2}{*}{ Sample Number } & \multirow[b]{2}{*}{ Sorbent Type } & \multicolumn{4}{|c|}{ Sample Port and Volume Information ${ }^{(2)}$} & \multirow[b]{2}{*}{$\begin{array}{c}\text { Mass } \\
\text { Gain (g) }\end{array}$} \\
\hline & & $\begin{array}{c}\text { Sample } \\
\text { Port } \\
\end{array}$ & $\begin{array}{l}\text { Flow Rate } \\
\text { (mL/min) }\end{array}$ & $\begin{array}{c}\text { Duration } \\
\text { (min) }\end{array}$ & $\begin{array}{c}\text { Volume } \\
\text { (L) }\end{array}$ & \\
\hline \multicolumn{7}{|l|}{ Samples: } \\
\hline S4087- A26-V18 & $\mathrm{NH}_{3} / \mathrm{NO}_{\mathbf{x}} / \mathrm{H}_{2} \mathrm{O}$ Train & 9 & 200.4 & 15.0 & 3.01 & 0.0489 \\
\hline S4087- A27-V19 & $\mathrm{NH}_{3} / \mathrm{NO}_{\mathbf{x}} / \mathrm{H}_{2} \mathrm{O}$ Train & 10 & 200.4 & 15.0 & 3.01 & 0.0469 \\
\hline S4087- A28-V20 & $\mathrm{NH}_{3} / \mathrm{NO}_{\mathrm{x}} / \mathrm{H}_{2} \mathrm{O}$ Train & 8 & 200.3 & 15.0 & 3.00 & 0.0445 \\
\hline S4087-A29-V21 & $\mathrm{NH}_{3} / \mathrm{NO}_{x} / \mathrm{H}_{2} \mathrm{O}$ Train & 10 & 200.3 & 15.0 & 3.00 & $0.0448^{(\mathrm{c})}$ \\
\hline S4087- A30-V22 & $\mathrm{NH}_{3} / \mathrm{NO}_{\mathbf{x}} / \mathrm{H}_{2} \mathrm{O}$ Train & 9 & 200.3 & 15.0 & 3.00 & 0.0419 \\
\hline S4087- A31-V23 & $\mathrm{NH}_{3} / \mathrm{NO}_{x} / \mathrm{H}_{2} \mathrm{O}$ Train & 10 & 200.3 & 15.0 & 3.00 & 0.0419 \\
\hline S4087- A32-V24 & $\mathrm{NH}_{3} / \mathrm{NO}_{2} / \mathrm{H}_{2} \mathrm{OBlank}$ & $n / a^{(b)}$ & $\mathrm{n} / \mathrm{a}$ & $\mathrm{n} / \mathrm{a}$ & $\mathrm{n} / \mathrm{a}$ & -0.0007 \\
\hline S4087-A33-V25 & $\mathrm{NH}_{3} / \mathrm{NO}_{2} / \mathrm{H}_{2} \mathrm{OBlank}$ & $\mathrm{n} / \mathrm{a}$ & $\mathrm{n} / \mathrm{a}$ & $\mathrm{n} / \mathrm{a}$ & $\mathrm{n} / \mathrm{a}$ & -0.0005 \\
\hline S4087- A34-V26 & $\mathrm{NH}_{3} / \mathrm{NO}_{\mathrm{x}} / \mathrm{H}_{2} \mathrm{OBlank}$ & $\mathrm{n} / \mathrm{a}$ & $\mathrm{n} / \mathrm{a}$ & $\mathrm{n} / \mathrm{a}$ & $\mathrm{n} / \mathrm{a}$ & -0.0006 \\
\hline
\end{tabular}

(a) Sampling information and dry-gas sample volumes, corrected to $0^{\circ} \mathrm{C}$ and 760 torr, were provided by WHC.

(b) $\quad \mathrm{n} / \mathrm{a}=$ not applicable.

(c) Results suspected to be biased by loss of glass from sorbent trap.

presence of the upstream $\mathrm{NH}_{3}$ traps resulted in NO concentrations that were about 1.3- to 1.6-fold less than those from unprotected $\mathrm{NO}_{2}$ traps. The $\mathrm{NO}_{2}$ concentrations were also potentially less following an $\mathrm{NH}_{3}$ trap.

The concentrations of $\mathrm{NO}_{2}$ and $\mathrm{NO}$ were $\leq 0.02$ and $1.04 \pm 0.10 \mathrm{ppmv}$, respectively. Blank-corrected $\mathrm{NO}_{2}^{-}$quantities in the sorbent traps averaged $\leq 0.0014 \mu \mathrm{mol}\left(\mathrm{NO}_{2}\right.$ samples) and $\leq 0.0694 \mu \mathrm{mol}$ (NO samples). Nitrite blank levels used to correct data were $0.0121 \pm 0.0017 \mu \mathrm{mol}$ in front (three of six blanks analyzed) and $0.0062 \pm 0.0002 \mu \mathrm{mol}$ in back (two of six blanks analyzed) sorbent sections. Although spiked blanks were not tested, blanks spiked with 0.0064 , $0.047,0.11$, and $0.74 \mu \mathrm{mol}$ of $\mathrm{NO}_{2}^{-}$during related sample jobs yielded percentage recoveries of $153 \pm 14 \%, 103 \pm 4 \%, 106 \pm 8 \%$, and $111 \pm 7 \%$, respectively (Clauss et al. 1994; Ligotke et al. 1994). The analyses of two samples were duplicated and yielded a repeatability of \pm 0 and $\pm 1 \%$. Two sample leachates were spiked with $0.25 \mathrm{ppm} \mathrm{NO}_{2}^{-}$and yielded a percentage recovery of 89 and $94 \%$. A 4-point calibration was performed over a concentration range of 0 to $0.5 \mu \mathrm{g} \mathrm{NO} \mathrm{NO}_{2}^{-}$per $\mathrm{mL}$ in the desorbing matrix.

2.4.3 Gravimetric Results. The mass concentration of material collected in the 5-trap sorbent trains, believed to be primarily water vapor, was $15.0 \pm 0.9 \mathrm{mg} / \mathrm{L}$. The result was based on an average mass gain of $45.1 \mathrm{mg}$ from all six $\mathrm{NH}_{3} / \mathrm{NO}_{2} / \mathrm{H}_{2} \mathrm{O}$ sample trains. A possible trend in sample mass (decreasing by about $12 \%$ ) with sample number was observed. The blank correction applied to the results was $+0.3 \mathrm{mg}$ per sample train, based on mass loss of $0.3 \pm 0.4 \mathrm{mg}$ per three blank 5-trap sorbent trains. The blanks, first assembled as complete 5-trap sorbent trains, accompanied samples from three related VSS sample jobs in December 1994 (TX-105, TX-118, and BX-104). Although no spiked blanks were tested, the percentage recovery of mass from three blank $\mathrm{H}_{2} \mathrm{O}$ traps spiked with $51 \mathrm{mg}$ of water was $103 \pm 2 \%$ during a related sample job (Clauss et al. 1994). 
Table 2.3 Inorganic Vapor Sample Results Obtained from a Heated Tube Inserted into the Headspace of Tank TX-105 on 12/20/94

Analytical Results ( $\mu \mathrm{mol})$

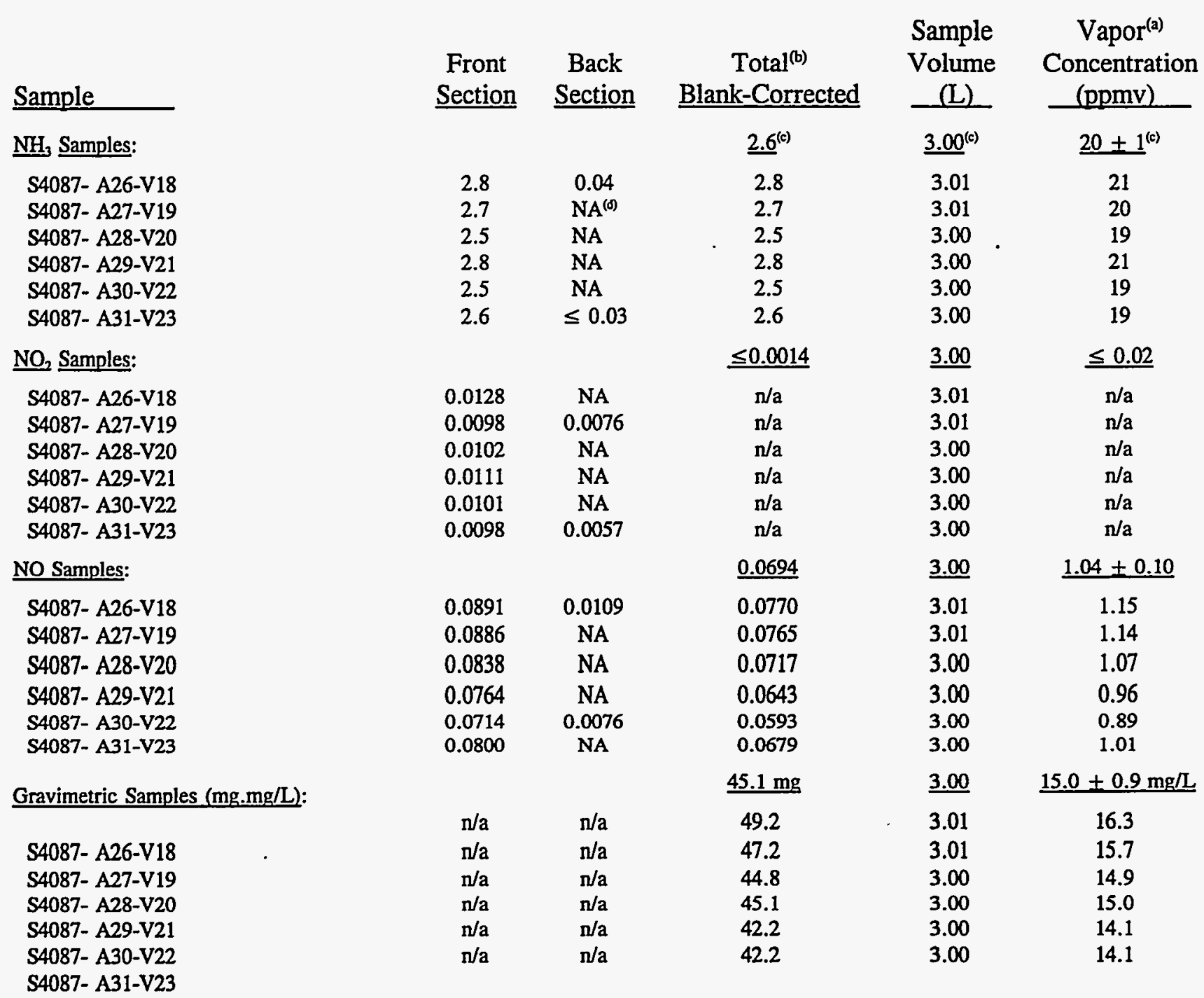

(a) Blank-corrected vapor concentrations were calculated using WHC-reported dry-air sample volumes (corrected to $0^{\circ} \mathrm{C}$ and 760 torr). In the calculation for concentration, the nitrite values (listed) were doubled to account for unanalyzed nitrate. Sample results were not corrected for percentage recovery of spiked samples or spiked blanks.

(b) Total blank-corrected analyte masses (nitrite for $\mathrm{NO}_{2}$ and $\mathrm{NO}$ ) were determined, when significant, by subtracting the quantity of analyte found in blanks from that found in samples. The level of analytes found in blanks is described in the subsections of Section 2.4 .

(c) Underlined values represent the average of the set samples. Concentration uncertainty equals \pm 1 standard deviation (absolute) for each set of samples. The use of " $\leq$ " is defined in Section 2.4.

(d) NA = not analyzed; $\mathrm{n} / \mathrm{a}=$ not applicable; $\mathrm{x}=$ not included in determination of average concentration. Only selected back sorbent sections were analyzed. Past results have shown back sections of $\mathrm{NH}_{3}$ samples to contain insignificant quantities of the analyte. 


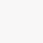




\subsection{Organic}

\subsection{SUMMA ${ }^{\text {Th }}$ Canister Preparation}

Before sending SUMMA ${ }^{\mathrm{m}}$ canisters out to the field for sampling, the canisters are cleaned and verified contaminant free according to PNL Technical Procedure PNL-TVP-02(a). The cleaning procedure uses an EnTech 3000 cleaning system that controls 1) filling the canisters with purified humid air and 2) evacuating, for several cycles with applied heat, before allowing the canister to evacuate overnight. The canister is filled a final time with purified humid air for analysis by PNL Technical Procedure PNL-TVP-01 ${ }^{(\mathrm{b})}$, which is a modification of U.S. Environmental Protection Agency (EPA) compendium Method TO-14. If the canister is verified as clean, free of TO-14 and unknown contaminants to a level of 5 parts per billion by volume ( $\mathrm{ppbv}$ ), the canister is evacuated to $5 \mathrm{mtorr}$, tagged, and stored for use in the field. Before sending the canisters out to the field for sampling, the canister vacuum is measured to determine if any leakage has occurred. If the vacuum has remained constant during storage, the canisters are prehumidified with $100 \mu \mathrm{L}$ of distilled water and labeled with a field-sampling identification. Canisters stored more than 30 but less than 60 days are re-evacuated and rehumidified before use. If stored more than 60 days, the canisters are recleaned and validated before use.

\subsection{Sample Analysis Methods}

The SUMMA ${ }^{\text {Ts }}$ canister sample was analyzed according to PNL Technical Procedure PNLTVP-03, Determination of TO-14 Volatile Organic Compounds in Hanford Waste Tank Headspace Samples Using SUMMA ${ }^{\text {th }}$ Passivated Canister Sampling and Gas Chromatographic-Mass Spectrometry Analysis, which is a modified version of EPA compendium Method TO-14. The method uses an EnTech cryoconcentration system interfaced with either a 5971 or a 5972 Hewlett Packard (HP) benchtop GC/MS. The EnTech concentrator is used to pull a metered volume of sample air from the SUMMA $^{\text {TM }}$ canister, cryogenically concentrate the air volume, then transfer the volume to the GC/MS for analysis. A $100-\mathrm{mL}$ volume of sample is measured and analyzed from the tank headspace. The organic components in the sampled air are separated on an analytical column, J\&W Scientific DB-1 phase, $60-\mathrm{m}$ by $0.32-\mathrm{mm}$ internal diameter with $3-\mu \mathrm{m}$ film thickness. The GC oven is programmed to run a temperature gradient beginning at $40^{\circ} \mathrm{C}$, holding for $5 \mathrm{~min}$, and ramping at $4^{\circ} \mathrm{C}$ per min to a final temperature of $260^{\circ} \mathrm{C}$, with a 5-min hold. Twenty-four hours before the analysis, the SUMMA ${ }^{7 x}$ canister samples were pressurized with purified air (Aadco Instruments, Inc., 1920 Sherwood St., Clearwater, Florida 34625). The starting pressure was first measured using a calibrated diaphragm gauge (Cole Parmer) then pressurized to a level exactly twice the original pressure. For example, if the canister had a starting pressure of 740 torr, it was pressurized to 1480 torr. This dilution was made as an effort to improve the precision of the analysis, as the sampling instrumentation was designed to perform at greater than atmospheric pressure. The sample dilution was taken into account when calculating the analysis results.

\footnotetext{
(a) Pacific Northwest Laboratory. 8/94. Cleaning SUMMA ${ }^{\text {Tx }}$ Canisters and the Validation of the Cleaning Process, PNL-TVP-02 (Rev. 0), PNL Technical Procedure, Richland, Washington.

(b) Pacific Northwest Laboratory. 8/94. Determination of TO-14 Volatile Organic Compounds in Ambient Air Using SUMMA ${ }^{\text {Tx }}$ Passivated Canister Sampling and Gas Chromatographic-Mass Spectrometric Analysis, PNL-TVP-01 (Rev. 0). PNL Technical Procedure, Richland, Washington.
} 
The instrument calibration mixture for the TO-14 analysis consists of the standard 39 organic analytes with an additional 14 tank-related compounds. Together, these 53 compounds that are directly quantified in this analysis make up the target analyte list (these 53 compounds will be referred to as target analytes). The calibration mixture was prepared by blending a commercially prepared 39-compound TO-14 calibration mixture with a 14-compound mixture created using a KinTech ${ }^{8}$ permeation-tube standard generation system. The operation of the permeation tube system follows the method detailed in Preparation of TO-14 Volatile Organic Compounds Gas Standards, PNL Technical Procedure PNL-TVP-06. The standard calibration mix was analyzed using seven aliquot sizes ranging from $5 \mathrm{~mL}$ to $300 \mathrm{~mL}$. Depending on the concentration of each analyte in the mixture, five, six, or seven points were used to construct the calibration curve. Butonoic acid was added to the mixture, but was not detected in the analysis. Butanal was recovered very poorly, producing a much lower than expected response. This results in a much higher measured amount reported in the sample analysis. While this problem is under investigation, butanal will continue to be measured as a tentatively identified compound. Performance-based detection limits for the target analytes will be developed as a pool of calibration data becomes available. Currently, the nominal detection limit of 5 ppbv is met.

The SUMMA ${ }^{\text {Ts }}$ canister samples were analyzed for permanent gases according to PNL Technical Procedure PNL-TVP-05, Analysis Method for the Determination of Permanent Gases in Hanford Waste Tank Vapor Samples Collected in SUMMA ${ }^{\text {TR }}$ Passivated Stainless Steel Canisters, with the exceptions listed in the following text and in the Quality Assurance/Quality Control section of this report. This method was developed in-house for the analysis of permanent gases defined as hydrogen $\left(\mathrm{H}_{2}\right)$, carbon dioxide $\left(\mathrm{CO}_{2}\right)$, carbon monoxide $(\mathrm{CO})$, methane $\left(\mathrm{CH}_{4}\right)$, and nitrous oxide $\left(\mathrm{N}_{2} \mathrm{O}\right)$ by GC/TCD and is not validated in any other laboratory. No previous work up of the sample canister is necessary before permanent gas analysis. Aliquots of sampled air are manually drawn from each canister into a 5-mL gas-tight syringe and directly injected into a GC/TCD fitted with a 1.0-mL injection loop. An aliquot of $5 \mathrm{~mL}$ is used so that the injection loop is flushed and filled with sample air, ensuring that no dilution of the sample takes place within the injection loop. One set of $\mathrm{GC}$ conditions is used to analyze for $\mathrm{CO}, \mathrm{CO}_{2}, \mathrm{~N}_{2} \mathrm{O}$, and $\mathrm{CH}_{4}$ using Helium (He) as the carrier gas. A second $\mathrm{GC}$ analysis is performed for $\mathrm{H}_{2}$ (using nitrogen as the carrier gas) to enhance the signal sensitivity and lower the detection limit for this analyte. A total of 30 to $60 \mathrm{~mL}$, depending upon the number of repeat analyses performed, may be drawn from each 6-L canister.

\subsection{Quality Assurance/Quality Control}

Before the tank sample was analyzed, a diagnostic check was performed on the GC/MS instrument by running an instrument "high sensitivity tune," as described in PNL-TVP-03. Upon satisfactory completion of the instrument diagnostic check, a blank volume of purified nitrogen was analyzed to check the cleanliness of the system. The instrument was then calibrated over 5 to 7 data points ranging from $5 \mathrm{ppbv}$ to $300 \mathrm{ppbv}$, using a standard gas mixture containing 39 volatile organic compounds listed in EPA compendium Method TO-14 and an additional 14 tank-related compounds. A gas mixture containing bromochloromethane, 1,4-difluorobenzene, and chlorobenzene- $\mathrm{d}_{5}$ was used as an internal standard (IS) for all blank, calibration standard, and sample analyses. Analyte responses from sample components, ISs, and standards were obtained from the extracted ion plot from their selected mass ion. The calibration curve was generated by calculating the relative response ratios of the IS to calibration standard responses and plotting the ratios against the ratio of the calibration-standard concentration (in ppbv) to the IS concentration. A least-squares linear-regression 
routine was applied to the data set to generate the best-fit line for each compound. The equation for that line was then used to quantify the target analytes found in the tank samples.

Standards for the permanent gas analysis were blended from commercially prepared and certified standards for each of the analytes reported in Table 3.6. The instrument was calibrated over three data points for $\mathrm{CO}, \mathrm{CO}_{2}, \mathrm{~N}_{2} \mathrm{O}$, and $\mathrm{CH}_{4}$ using $\mathrm{He}$ as a carrier gas, and then the samples were analyzed. The carrier was changed to $\mathrm{N}_{2}$, the calibration was performed for $\mathrm{H}_{2}$ only, and the samples were reanalyzed. A least-squares linear-regression routine was applied to the data set to generate the best fit for each compound. The quantitation for each analyte was performed by direct comparison of sample analyte peaks to the plot generated for the compound. The lowest calibration standard for each analyte is reported as the method detection limit. An MDL for the instrument has not been determined. An $\mathrm{N}_{2}$ reagent blank was not analyzed with this set of samples. The ambient air sample collected $\sim 10 \mathrm{~m}$ upwind of TX-105 and the ambient air collected through the VSS were used as method blanks and used to determine the potential for analyte interferences in the samples. Continuing calibration standards for this sample set fell within $\pm 25 \%$ of the expected concentrations for the analytes reported.

3.3.1 Quantitation Results of Target Analytes. The quantitative-analysis results for the target analytes were calculated directly from the calibration curve generated using the IS method described above and in PNL-TVP-03. The conversion from $\mathrm{ppbv}$ to $\mathrm{mg} / \mathrm{m}^{3}$ assumes standard temperature and pressure (STP) conditions of 760 torr and $273 \mathrm{~K}$ and was calculated directly from the following equation:

$$
\mathrm{mg} / \mathrm{m}^{3}=\frac{(\mathrm{ppbv} / 1000) \times \mathrm{g} \mathrm{mol} \mathrm{wt} \mathrm{of} \mathrm{compound}}{22.4 \mathrm{~L} / \mathrm{mol}}
$$

3.3.2 Identification and Quantitation of Tentatively Identified Compounds. The tentatively identified compounds (TICs) are determined by mass-spectral interpretation and comparison of the spectra with the EPA/NIST/WILEY Library, which is a part of the HP 5971/5972 instrument operating system. Chromatographic peaks with an area count greater than, or equal to, one tenth of the total area count of the nearest eluting IS are tentatively identified and quantitatively estimated. The quality of the mass-spectral searches was then reviewed by the principal investigators before the identification was assigned to each chromatographic peak.

The concentration of each TIC was estimated using a relative response factor calculated using the total peak area for the nearest eluting IS. The IS peak area was used to calculate a response factor using the IS concentration in $\mathrm{mg} / \mathrm{m}^{3}$ :

$$
\text { Response Factor }=\frac{\text { IS conc. }\left(\mathrm{mg} / \mathrm{m}^{3}\right)}{\text { IS peak area }}
$$

The calculated response factor was then multiplied by the TIC peak area to give an estimated concentration for that compound. 
The ppbv concentrations are calculated from $\mathrm{mg} / \mathrm{m}^{3}$ and the molecular weight of the analyte.

$$
\text { TIC in } \mathrm{ppbv}=\frac{\mathrm{TIC}\left(\mathrm{mg} / \mathrm{m}^{3}\right) \times 22.4 \mathrm{~L} / \mathrm{mol} \mathrm{x} 1000}{\text { TIC } \mathrm{g} \mathrm{mol} \mathrm{wt}}
$$

The IS level added to all blank, standard, and sample injections was 104 ppbv for bromochloromethane, $101 \mathrm{ppbv}$ for 1,4-difluorobenzene, and $98.5 \mathrm{ppbv}$ for chlorobenzene- $\mathrm{d}_{5}$. The IS concentrations were converted from $\mathrm{ppbv}$ to $\mathrm{mg} / \mathrm{m}^{3}$ at STP using a molecular weight of 129.39 ( $\mathrm{g} / \mathrm{mol})$ for bromochloromethane, 114.09 for 1,4-difluorobenzene, and 117.6 for chlorobenzene- $\mathrm{d}_{5}$. All sample concentrations were multiplied by a factor of two to account for the dilution step described in Section 3.2.

\subsection{Analysis Results}

The results from the GC/MS analysis of the tank-headspace samples are presented in Tables 3.1, 3.2, 3.3 and 3.4. The results of GC/MS analysis of ambient air sample collected upwind of Tank TX-105 and through the VSS near Tank TX-105 are presented in Table 3.5. The GC/MS analysis results for permanent gases for both the ambient samples and from the tank headspace are presented in Table 3.6. A representative total ion chromatogram showing the identity of major constituents is given in Figure 3.1.

Table 3.1 lists the quantitative results for compounds listed as target analytes. Six compounds were above the MDL. Acetone and carbon tetrachloride were approximately $87 \%$ of the total concentration $\left(5.10 \mathrm{mg} / \mathrm{m}^{3}\right)$ of the target analytes.

Table 3.2 lists the semi-quantitative results for the TICs. Only one species, an unknown C5 ether, was observed in this sample. The normal paraffin hydrocarbons (NPHs), defined as n-alkanes from $C_{11}$ to $C_{15}$, were not detected. It should be noted that because the SUMMA ${ }^{\text {mat }}$ canisters were not heated at the time of analysis, the NPH concentrations listed after the retention time of decane may not be a true accounting of all the NPH in the sample. Similarly, polar compounds, which may adhere to the inside surface of the canister, may also be under represented in this analysis. The total concentration of the TIC compounds was found to be $0.05 \mathrm{mg} / \mathrm{m}^{3}$.

SUMMA $^{\mathrm{Th}}$ canister PNL 153 was analyzed in replicate for target analytes and TICs to determine precision. The analytical and relative percent difference (RPD) results are presented in Tables 3.3 and 3.4. The RPD was calculated for analytes detected above the MDL and found in both replicates. All target analytes had an RPD of less than $10 \%$. The one TIC detected, the unknown $\mathrm{C}_{5}$ ether, had an RPD of less than $10 \%$.

Table 3.5 lists results of target analyte analyses for ambient air collected upwind of Tank TX-105 and ambient air collected through the VSS. Only one compound, 2-butanone, was detected in the upwind sample. No organic compounds were observed through the VSS.

Table 3.6 lists results of permanent gas analysis from samples collected from the headspace of Tank TX-105, ambient air collected $\sim 10 \mathrm{~m}$ upwind of the tank, and ambient air collected through the VSS. The only permanent gas observed in the headspace was $\mathrm{CO}_{2}$. The carbon dioxide in the headspace was at a lower concentration than in ambient air. A replicate analysis was performed on one of the samples collected from this tank (see footnote $\mathrm{C}$ in Table 3.6). 


\subsection{Conclusions}

The concentrations of selected inorganic and organic compounds were determined from samples of the headspace of Tank TX-105 on 12/20/94. Sampling and analysis methods followed those described by Ligotke et al. (1994) for samples obtained from C-103, a tank containing a relatively complex headspace composition. Method-validation measurements during that study did appear to validate the trapping and analysis of $\mathrm{NH}_{3}$, but did not eliminate the possibility of interferences that could affect $\mathrm{NO}_{\mathrm{x}}$ results. It is recommended that additional control samples be obtained if a tank is discovered in the future to contain significant quantities of $\mathrm{NO}_{\mathrm{x}}$. In the current sample job, $\mathrm{NO}_{x}$ samples were obtained after first passing the sample flow through an $\mathrm{NH}_{3}$ trap. The average and standard deviation of the concentration results from inorganic sorbent trains were $20 \pm 1$ ppmv $\left(\mathrm{NH}_{3}\right), \leq 0.02 \mathrm{ppmv}\left(\mathrm{NO}_{2}\right), 1.04 \pm 0.10 \mathrm{ppmv}(\mathrm{NO})$, and $15.0 \pm 0.9 \mathrm{mg} / \mathrm{L}$ (vapor-mass concentration). The vapor-mass concentration is expected to consist largely of water vapor. The mass results displayed a possible minor $(-12 \%)$ trend with the order in which the 6 sorbent-train samples were obtained (in 3 pairs) from the headspace of TX-105.

Organic analysis of the tank-headspace samples from Tank TX-105 identified six target analytes above the 5-ppbv MDL and two TICs above the 10-ppbv reporting cutoff. One TIC was indentified in two or more of the SUMMA ${ }^{\mathrm{TM}}$ samples. The total target analytes concentration accounted for $99 \%$ of the total compounds indentified by both the target analyte and the TIC analyses. Acetone and carbon tetrachloride accounted for $88 \%$ of the target analytes and $87 \%$ of the total compounds identified by both analyses. Acetaldehyde and an unknown $\mathrm{C}_{5}$ ether were the only TIC compounds identified. The $C_{5}$ ether was identified in all three of the SUMMA ${ }^{\text {Ts }}$ canisters; acetaldehyde was identified in only one SUMMA ${ }^{\mathrm{TM}}$ canister. The $\mathrm{C}_{5}$ ether was the highest concentration TIC measured. Results of replicate analysis on a single SUMMA ${ }^{\mathrm{nt}}$ canister observed six target analytes having RPDs of less than $10 \%$. The $\mathrm{C}_{5}$ ether has an RPD of $15 \%$ for the TIC analysis. The results of the target analyte and TIC analysis on the ambient air sample collected $\sim 10 \mathrm{~m}$ upwind of Tank TX-105 identified 2-butanone in the sample. No target-analytes or TICs were identified in the ambient air through the VSS sample. One permanent gas, $\mathrm{CO}_{2}$, was also detected in the tank-headspace samples at levels below those found in the ambient air. It is suspected that alkaline conditions in the tank cause this reduction in $\mathrm{CO}_{2}$.

\subsection{References}

Clauss, T. W., M. W. Ligotke, B. D. McVeety, K. H. Pool, R. B. Lucke, J. S. Fruchter, and S. C. Goheen. 1994. Vapor Space Characterization of Waste Tank 241-BY-104: Results from Samples Collected on 6/24/94. PNL-10208. Pacific Northwest Laboratory, Richland, Washington.

Ligotke, M. W., K. H. Pool, and B. D. Lerner. 1994. Vapor Space Characterization of Waste Tank 241-C-103: Inorganic Results from Sample Job 7B (5/12/94 - 5/25/94). PNL-10172, Pacific Northwest Laboratory, Richland, Washington.

Mahlum, D. 1994. Toxicological Evaluation of Analytes from Tank 241-C-103. PNL-10189, Pacific Northwest Laboratory, Richland, Washington. 
•

. 


\subsection{Further Reading}

Pacific Northwest Laboratory. Analytical Laboratory Procedure Compendium. Procedures PNLALO-212, -226, -271. PNL-MA-599, Richland, Washington.

Pacific Northwest Laboratory. Quality Assurance Manual, Part 2: Good Practices Standard. PNLMA-70, Part 2, Richland, Washington.

Pacific Northwest Laboratory. Quality Assurance Plan for Activities Conducted by the Analytical Chemistry Laboratory (ACL). MCS-033, Analytical Chemistry Laboratory, Richland, Washington.

Pacific Northwest Laboratory. 1994. Determination of TO-14 Volatile Organic Compounds in Hanford Waste Tank Headspace Samples Using SUMMA ${ }^{\mathrm{Tx}}$ Passivated Canister Sampling and Gas Chromatographic-Mass Spectrometry Analysis, PNL-TVP-03 (Rev. 0), PNL Technical Procedure, Richland, Washington.

Pacific Northwest Laboratory. 1994. Sample Shipping and Receiving Procedure - DRAFT for PNL Waste Tank Samples. PNL-TVP-07 (Rev. 0), PNL Technical Procedure, Richland, Washington. 
Table 3.1 Positively Identified and Quantitated Target Organic Analytes ${ }^{(2)}$ of Samples Collected from the Headspace of Tank TX-105 in SUMMA ${ }^{\mathrm{TM}}$ Canisters on $12 / 20 / 94$

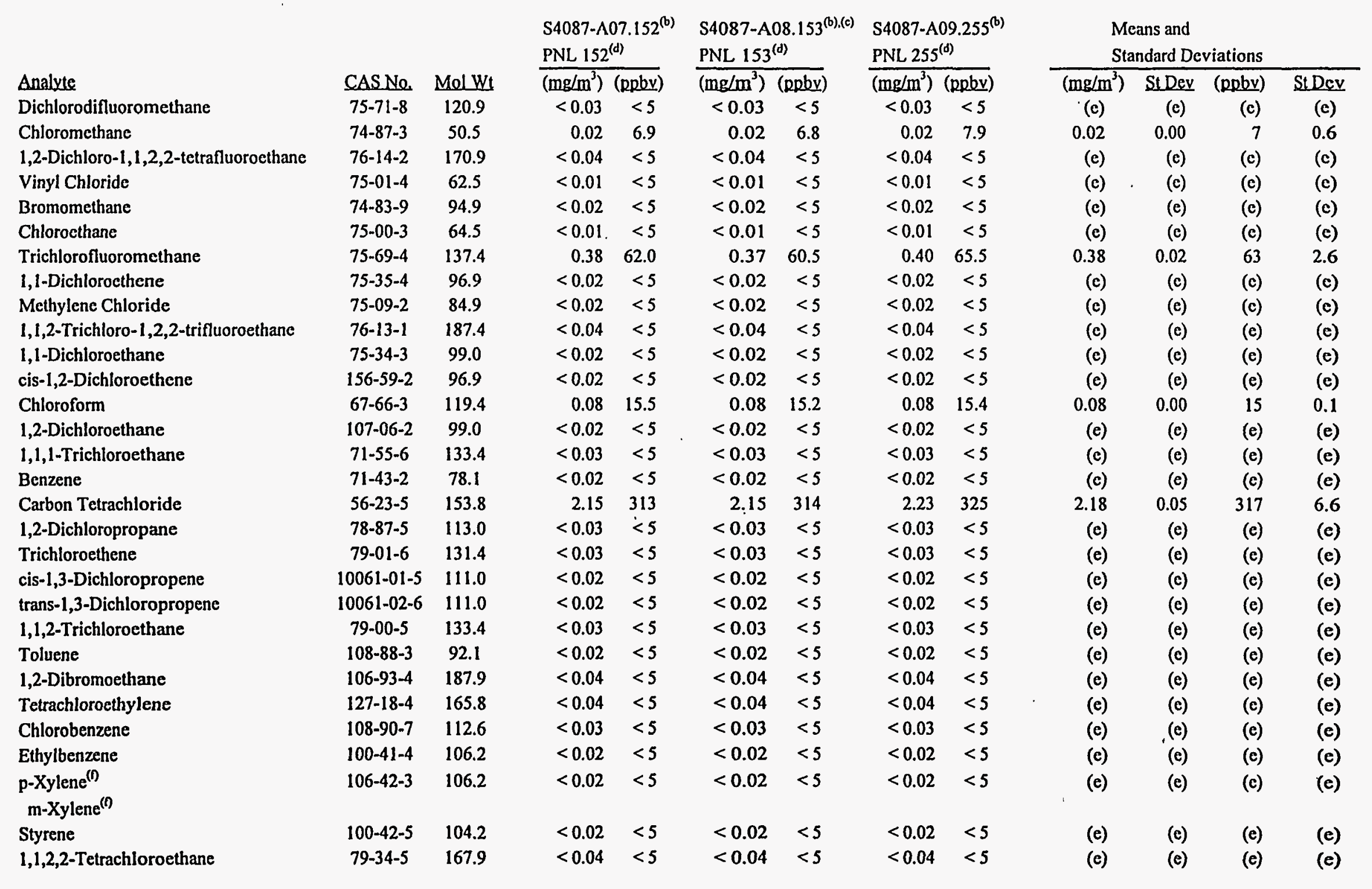




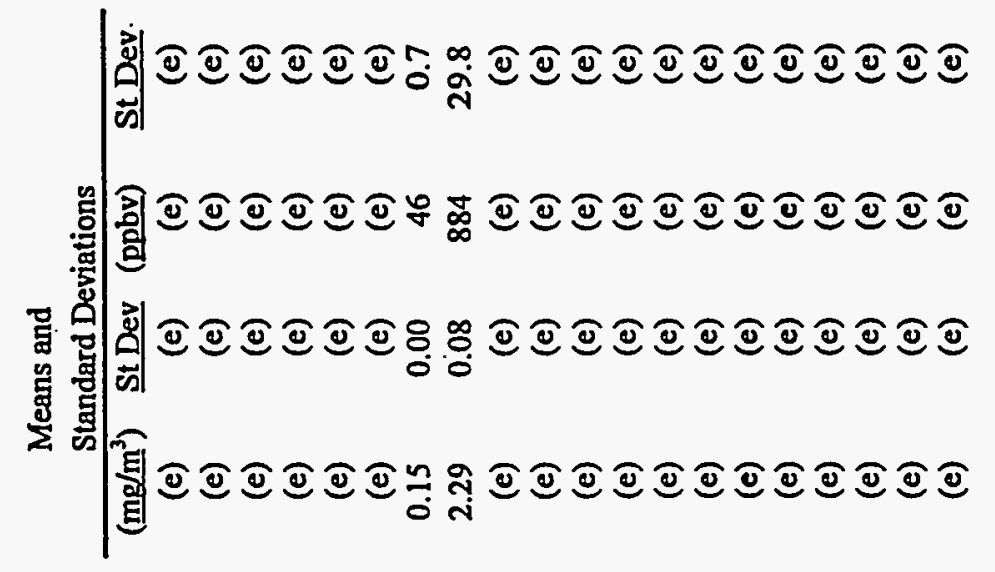

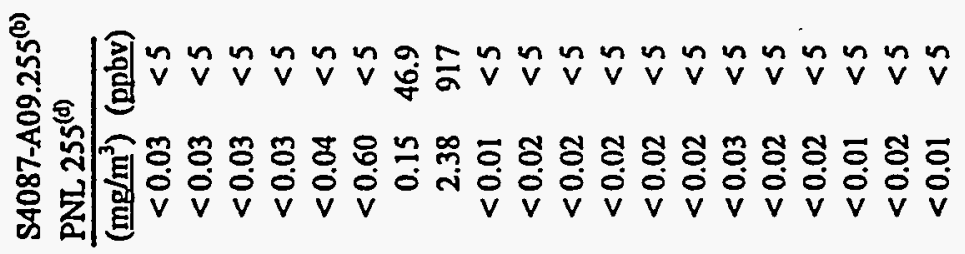

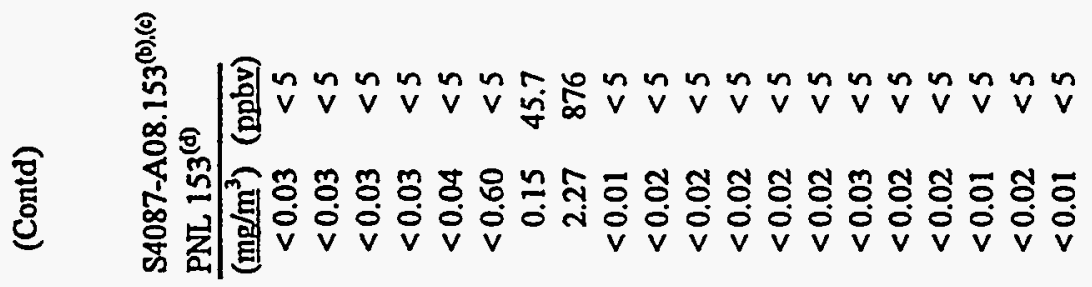

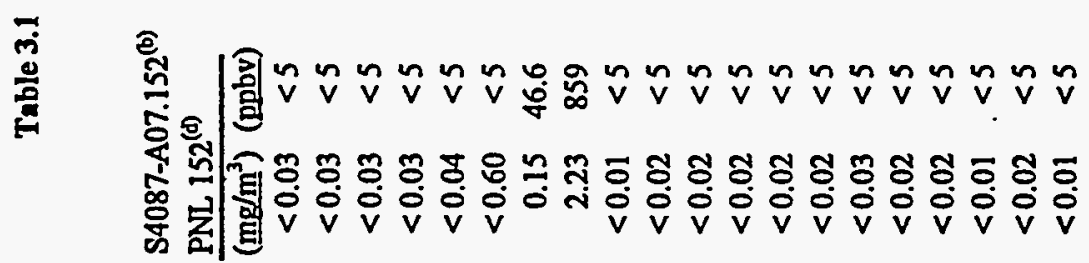

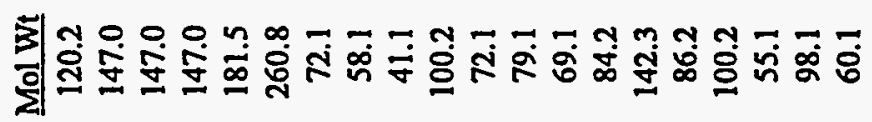

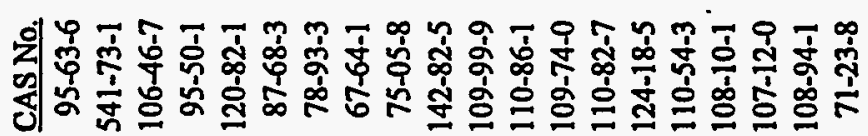
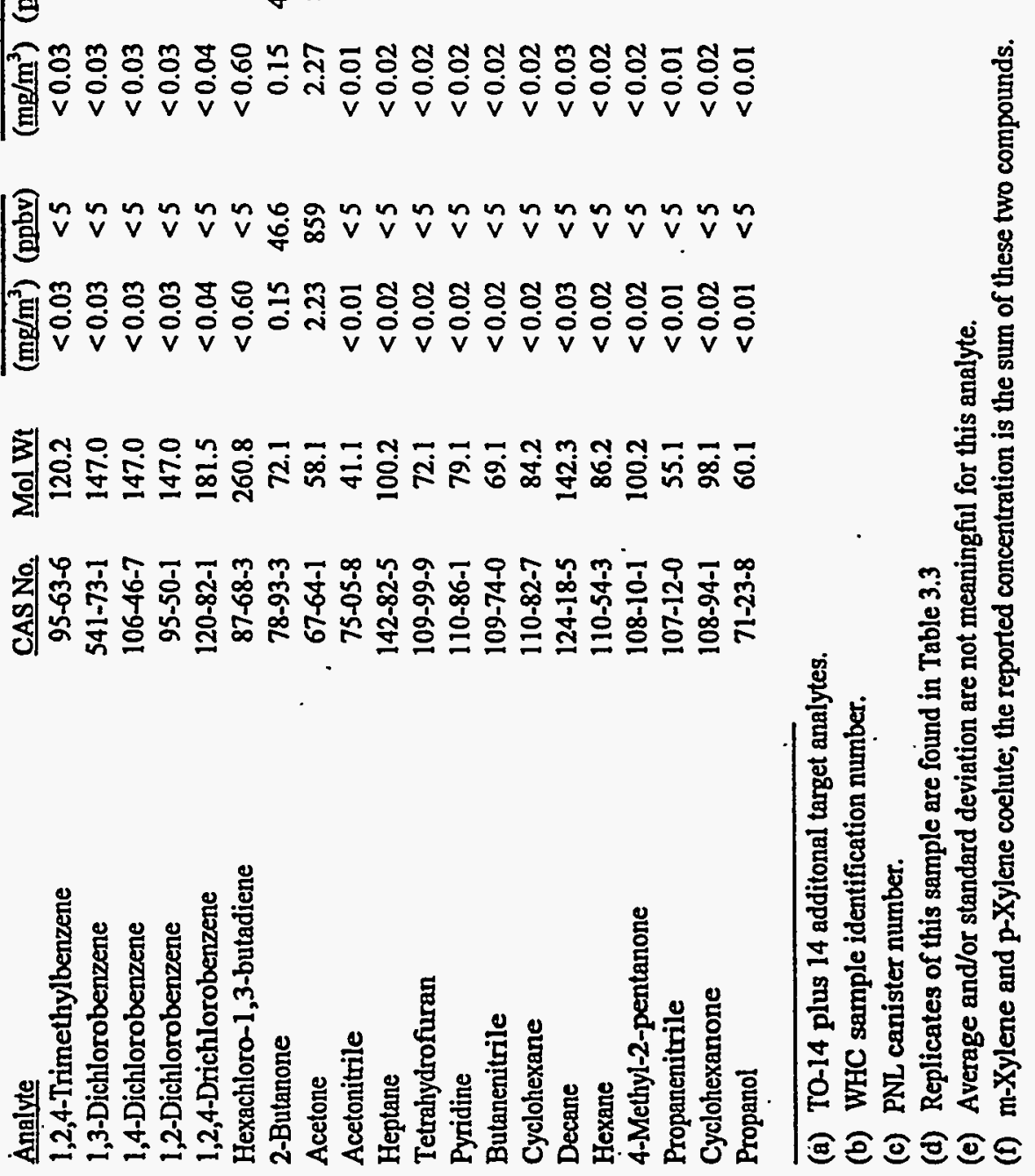
Table 3.2 Tentatively Identified Compounds and Estimated Concentrations ${ }^{()}$of Samples from the Headspace of Tank TX-105 in SUMMA ${ }^{\mathrm{TM}}$ Canisters Collected on $12 / 20 / 94$

\begin{tabular}{|c|c|c|c|c|c|c|c|c|c|}
\hline \multirow{2}{*}{$\begin{array}{l}\text { Tentatively } \\
\text { Identified Compound }^{(e)}\end{array}$} & \multirow[b]{2}{*}{ CAS No. ${ }^{(e)}$} & \multirow{2}{*}{$\begin{array}{l}\text { Mol } \\
\text { Wt }\end{array}$} & \multirow{2}{*}{$\begin{array}{l}\text { Ret } \\
\text { Time }\end{array}$} & \multicolumn{2}{|c|}{$\begin{array}{l}\text { S4087-A07.152 } \\
\text { PNL } 152^{(\mathrm{d})}\end{array}$} & \multicolumn{2}{|c|}{$\begin{array}{l}\text { S4087-A08.153 (b),(c) } \\
\text { PNL } 153^{(\text {(d) }}\end{array}$} & \multicolumn{2}{|c|}{$\begin{array}{l}\text { S4087-A09.255(b) } \\
\text { PNL 255 }\end{array}$} \\
\hline & & & & $\left(\mathrm{mg} / \mathrm{m}^{3}\right)$ & $\overline{(\mathrm{ppbv})}$ & $\left(\mathrm{mg} / \mathrm{m}^{3}\right)$ & (ppbv) & $\left(\mathrm{mg} / \mathrm{m}^{3}\right)$ & \\
\hline & $75-07-0$ & 44 & 5.1 & $<0.02$ & $<10.0$ & $<0.02$ & $<10.0$ & 0.06 & \\
\hline nknown $\mathrm{C} 5$ ether & & 88 & 12.3 & 0.03 & 84 & 0.06 & 153 & 0.07 & \\
\hline
\end{tabular}

Means and

Standard Deviations

$\begin{array}{rrrr}\left(\mathrm{mg} / \mathrm{m}^{3}\right) & \text { St Dev } & \text { (ppbv) } & \text { St Dev } \\ (\mathrm{f}) & (\mathrm{f}) & (\mathrm{f}) & (\mathrm{f}) \\ 0.05 & 0.02 & 13.7 & 4.8\end{array}$

(a) Semi-quantitative estimate calculated using concentration of closest eluting IS.

(b) WHC sample identification number.

(c) Replicates of this sample are found in Table 3.4

$N$ (d) PNL SUMMA ${ }^{\mathrm{TM}}$ canister number.
$\mathrm{N}$ (c) Obtained by mass spectral interpretation amd comparison with the EPANIST/WILEY Library.

(f) Mean and/or standard deviation are not meaningful for this analyte. 
Table 3.3 Positively Identified and Quantitated Target Organic Analytes ${ }^{\left({ }^{()}\right.}$of Replicate Analyses of a Single SUMMA ${ }^{\text {TM }}$ Canister Collected from the Headspace of Tank TX-105 on 12/20/94

Analyte
Dichlorodifluoromethane
Chloromethane
1,2-Dichloro-1,1,2,2-tetrafluoroethane
Vinyl Chloride
Bromomethane
Chloroethane
Trichlorofluoromethane
1,1-Dichloroethene
Methylene Chloride
1,1,2-Trichloro-1,2,2-trifluoroethane
1,1-Dichloroethane
cis-1,2-Dichloroethene
Chloroform
1,2-Dichloroethane
1,1,1-Trichloroethane
Benzene
Carbon Tetrachloride
1,2-Dichloropropane
Trichloroethene
cis-1,3-Dichloropropene
trans-1,3-Dichloropropene
1,1,2-Trichloroethane
Toluene
1,2-Dibromoethane
Tetrachloroethylene
Chlorobenzene
Ethylbenzene
p-Xylene
m-Xylene
Styrene

\begin{tabular}{|c|c|c|c|c|c|c|}
\hline \multirow[b]{2}{*}{ CAS No. } & \multirow[b]{2}{*}{ Mol Wt } & \multicolumn{2}{|c|}{$\begin{array}{l}\text { S4087-A08.153 } \\
\text { PNL } 153^{(b)}\end{array}$} & \multicolumn{2}{|c|}{$\begin{array}{l}\text { S4087-A08.153(b) } \\
\text { PNL } 153^{(0)}\end{array}$} & \multirow{2}{*}{$\begin{array}{l}\text { Relative } \\
\text { Percent } \\
\text { Difference } \\
\%\end{array}$} \\
\hline & & $\left(\mathrm{mg} / \mathrm{m}^{3}\right)$ & $\overline{p b v)}$ & $\left(\mathrm{mg} / \mathrm{m}^{3}\right)$ & $\overline{(\mathrm{ppbv})}$ & \\
\hline $75-71-8$ & 120.9 & $<0.03$ & $<5$ & $<0.03$ & $<5$ & \\
\hline $74-87-3$ & 50.5 & 0.02 & 6.8 & 0.02 & 7.0 & 0.0 \\
\hline $76-14-2$ & 170.9 & $<0.04$ & $<5$ & $<0.04$ & $<5$ & \\
\hline $75-01-4$ & 62.5 & $<0.01$ & $<5$ & $<0.01$ & $<5$ & \\
\hline $74-83-9$ & 94.9 & $<0.02$ & $<5$ & $<0.02$ & $<5$ & \\
\hline $75-00-3$ & 64.5 & $<0.01$ & $<5$ & $<0.01$ & $<5$ & \\
\hline $75-69-4$ & 137.4 & 0.37 & 60.5 & 0.37 & 59.6 & 0.0 \\
\hline $75-35-4$ & 96.9 & $<0.02$ & $<5$ & $<0.02$ & $<5$ & \\
\hline $75-09-2$ & 84.9 & $<0.02$ & $<5$ & $<0.02$ & $<5$ & \\
\hline $76-13-1$ & 187.4 & $<0.04$ & $<5$ & $<0.04$ & $<5$ & \\
\hline $75-34-3$ & 99.0 & $<0.02$ & $<5$ & $<0.02$ & $<5$ & \\
\hline $156-59-2$ & 96.9 & $<0.02$ & $<5$ & $<0.02$ & $<5$ & \\
\hline $67-66-3$ & 119.4 & 0.08 & 15.2 & 0.08 & 15.1 & 0.0 \\
\hline $107-06-2$ & 99.0 & $<0.02$ & $<5$ & $<0.02$ & $<5$ & \\
\hline $71-55-6$ & 133.4 & $<0.03$ & $<5$ & $<0.03$ & $<5$ & \\
\hline $71-43-2$ & 78.1 & $<0.02$ & $<5$ & $<0.02$ & $<5$ & \\
\hline $56-23-5$ & 153.8 & 2.15 & 314 & 2.13 & 310 & 0.9 \\
\hline $78-87.5$ & 113.0 & $<0.03$ & $<5$ & $<0.03$ & $<5$ & \\
\hline $79-01-6$ & 131.4 & $<0.03$ & $<5$ & $<0.03$ & $<5$ & \\
\hline $61-01-5$ & 111.0 & $<0.02$ & $<5$ & $<0.02$ & $<5$ & \\
\hline $61-02-6$ & 111.0 & $<0.02$ & $<5$ & $<0.02$ & $<5$ & \\
\hline $79-00-5$ & 133.4 & $<0.03$ & $<5$ & $<0.03$ & $<5$ & \\
\hline $108-88-3$ & 92.1 & $<0.02$ & $<5$ & $<0.02$ & $<5$ & \\
\hline $106-93-4$ & 187.9 & $<0.04$ & $<5$ & $<0.04$ & $<5$ & \\
\hline $127-18-4$ & 165.8 & $<0.04$ & $<5$ & $<0.04$ & $<5$ & \\
\hline $108-90-7$ & 112.6 & $<0.03$ & $<5$ & $<0.03$ & $<5$ & \\
\hline $100-41-4$ & 106.2 & $<0.02$ & $<5$ & $<0.02$ & $<5$ & \\
\hline $106-42-3$ & 106.2 & $<0.02$ & $<5$ & $<0.02$ & $<5$ & \\
\hline $100-42-5$ & 104.2 & $<0.02$ & $<5$ & $<0.02$ & $<5$ & \\
\hline
\end{tabular}


Table 3.3 (Contd)

Analyte
1,3,5-Trimethylbenzene
1,2,4-Trimethylbenzene
1,3-Dichlorobenzene
1,4-Dichlorobenzene
1,2-Dichlorobenzene
1,2,4-Drichlorobenzene
Hexachloro-1,3-butadiene
2-Butanone
Acetone
Acetonitrile
Heptane
Tetrahydrofuran
Pyridine
Butanenitrile
Cyclohexane
Decane
Hexane
4-Methyl-2-pentanone
Propanenitrile
Cyclohexanone
Propanol

\begin{tabular}{|c|c|c|c|c|c|c|}
\hline \multirow[b]{2}{*}{ CAS No, } & \multirow[b]{2}{*}{ Mol Wt } & \multicolumn{2}{|c|}{ 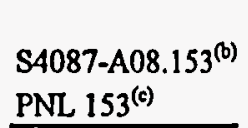 } & \multicolumn{2}{|c|}{$\begin{array}{l}\text { S4087-A08.153(b) } \\
\text { PNL 153 }\end{array}$} & \multirow{2}{*}{$\begin{array}{l}\text { Relative } \\
\text { Percent } \\
\text { Difference } \\
\% \frac{\%}{6}\end{array}$} \\
\hline & & $\left(\mathrm{mg} / \mathrm{m}^{3}\right)$ & $\overline{\text { phv) }}$ & $\left(\mathrm{mg} / \mathrm{m}^{3}\right)$ & (ppbv) & \\
\hline $108-67-8$ & 120.2 & $<0.03$ & $<5$ & $<0.03$ & $<5$ & \\
\hline $95-63-6$ & 120.2 & $<0.03$ & $<5$ & $<0.03$ & $<5$ & \\
\hline $541-73-1$ & 147.0 & $<0.03$ & $<5$ & $<0.03$ & $<5$ & \\
\hline $106-46-7$ & 147.0 & $<0.03$ & $<5$ & $<0.03$ & $<5$ & \\
\hline $95-50-1$ & 147.0 & $<0.03$ & $<5$ & $<0.03$ & $<5$ & \\
\hline $120-82-1$ & 181.5 & $<0.04$ & $<5$ & $<0.03$ & $<5$ & \\
\hline $87-68-3$ & 260.8 & $<0.60$ & $<5$ & $<0.04$ & $<5$ & \\
\hline $78-93-3$ & 72.1 & 0.15 & 45.7 & 0.15 & 47.5 & 0.0 \\
\hline $67-64-1$ & 58.1 & 2.27 & 876 & 2.22 & 858 & 2.2 \\
\hline $75-05-8$ & 41.1 & $<0.01$ & $<5$ & $<0.01$ & $<5$ & \\
\hline $142-82-5$ & 100.2 & $<0.02$ & $<5$ & $<0.02$ & $<5$ & \\
\hline 109-99-9 & 72.1 & $<0.02$ & $<5$ & $<0.02$ & $<5$ & \\
\hline $110-86-1$ & 79.1 & $<0.02$ & $<5$ & $<0.02$ & $<5$ & \\
\hline $109-74-0$ & 69.1 & $<0.02$ & $<5$ & $<0.02$ & $<5$ & \\
\hline $110-82-7$ & 84.2 & $<0.02$ & $<5$ & $<0.02$ & $<5$ & \\
\hline $124-18-5$ & 142.3 & $<0.03$ & $<5$ & $<0.02$ & $<5$ & \\
\hline $110-54-3$ & 86.2 & $<0.02$ & $<5$ & $<0.02$ & $<5$ & \\
\hline $108-10-1$ & 100.2 & $<0.02$ & $<5$ & $<0.03$ & $<5$ & \\
\hline $107-12-0$ & 55.1 & $<0.01$ & $<5$ & $<0.02$ & $<5$ & \\
\hline $108-94-1$ & 98.1 & $<0.02$ & $<5$ & $<0.02$ & $<5$ & \\
\hline $71-23-8$ & 60.1 & $<0.01$ & $<5$ & $<0.01$ & $<5$ & \\
\hline
\end{tabular}

(a) TO-14 plus 14 additonal target analytes.

(b) WHC sample identification number.

(c) PNL canister number.

(d) $\mathrm{m}$-Xylene and $\mathrm{p}$-Xylene coelute; the reported concentration is the sum of these two compounds. 
Table 3.4 Tentatively Identified Compounds and Estimated Concentrations ${ }^{(\mathbf{a})}$ of Replicate Analyses of a Single SUMMA ${ }^{\text {TM }}$ Canister Collected from the Headspace of Tank TX-105 on 12/20/94

\begin{tabular}{|c|c|c|c|c|c|c|c|c|}
\hline \multirow{2}{*}{$\begin{array}{l}\text { Tentatively } \\
\text { Identified Compound }^{(\mathrm{d})}\end{array}$} & \multirow[b]{2}{*}{$\mathrm{CASNo}^{(\mathrm{d})}$} & \multirow{2}{*}{$\begin{array}{l}\text { Mol } \\
\text { Wt }\end{array}$} & \multirow{2}{*}{$\begin{array}{c}\text { Ret } \\
\text { Time }\end{array}$} & \multicolumn{2}{|c|}{ 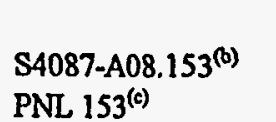 } & \multicolumn{2}{|c|}{ 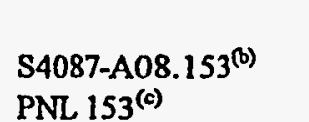 } & \multirow{2}{*}{$\begin{array}{l}\text { Relative } \\
\text { Percent } \\
\text { Difference } \\
\%\end{array}$} \\
\hline & & & & $\left(\mathrm{mg} / \mathrm{m}^{3}\right)$ & (ppbv) & $\left(\mathrm{mg} / \mathrm{m}^{3}\right)$ & (ppbv) & \\
\hline Acetaldehyde & $75-07-0$ & 44 & 5.1 & $<0.02$ & $<10.0$ & $<0.02$ & $<10.0$ & \\
\hline Unknown C5 ether & & 88 & 12.3 & 0.06 & 15.3 & 0.07 & 17.8 & 15.4 \\
\hline
\end{tabular}

(a) Semi-quantitative estimate calculated using concentration of closest eluting IS.

(b) WHC sample identification number.

(c) PNL SUMMA ${ }^{\mathrm{TM}}$ canister number.

(d) Obtained by mass spectral interpretation amd comparison with the EPANIST/WILEY Library. 
Table 3.5 Positively Identified and Quantitated Target Organic Analytes ${ }^{(a)}$ for Ambient Air Collected Near Tank TX-105 in a SUMMA ${ }^{\mathrm{TM}}$ Canister on 12/20/94

\begin{tabular}{|c|c|c|c|c|}
\hline & & & $\begin{array}{l}\text { Upwind } \\
\text { S4087-A01.013 } \\
\text { PNL 013 } \\
\text { (c) }\end{array}$ & $\begin{array}{l}\text { Through VSS } \\
\text { S4087-A02.116 } \\
\text { PNL 116 } \\
\text { P(c) }\end{array}$ \\
\hline Analyte & CAS No. & Mol Wt & $\left(\mathrm{mg} / \mathrm{m}^{3}\right) \quad(\mathrm{ppbv}$ & $\left(\mathrm{mg} / \mathrm{m}^{3}\right) \quad(\mathrm{ppbv})$ \\
\hline 2-Butanone & $78-93-3$ & 72.1 & 0.12 & $<0.02<5$ \\
\hline
\end{tabular}

(a) TO-14 plus 14 additonal analytes.

(b) WHC sample identification number.

(c) PNL canister number. 
Table 3.6 Permanent Gas Analysis Results for Samples Collected from the Headspace of Tank TX-105 and for Ambient Air Collected Near Tank TX-105 in SUMMA ${ }^{\text {TM }}$ Canisters on 12/20/94

\begin{tabular}{|c|c|c|c|c|c|}
\hline & $\begin{array}{l}\text { Ambient Air } \\
\text { Upwind } \\
\text { S4087-A01.013(a) }\end{array}$ & $\begin{array}{l}\text { Ambient Air } \\
\text { Through VSS } \\
\text { S4087-A02.116(a) }\end{array}$ & $\begin{array}{l}\text { Sample } 6 \\
\text { S4087-A07.152(a) }\end{array}$ & $\begin{array}{l}\text { Sample } 7 \\
\text { S4087-A08.153(a) }\end{array}$ & 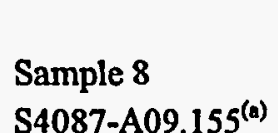 \\
\hline Permanent Gas & PNL $013^{(b)}$ & PNL $116^{(6)}$ & PNL $152^{(b)}$ & PNL $153^{(b)}$ & PNL $255^{(0),(c)}$ \\
\hline Analyte & (ppmv) & (ppmv) & (ppmv) & (ppmv) & (ppmv) \\
\hline Hydrogen & $<98.6$ & $<98.6$ & $<98.6$ & $<98.6$ & $<98.6$ \\
\hline Methane & $<61$ & $<61$ & $<61$ & $<61$ & $<61$ \\
\hline Carbon Dioxide & 385 & 387 & 153 & 133 & 182 \\
\hline Carbon Monoxide & $<12$ & $<12$ & $<12$ & $<12$ & $<12$ \\
\hline Nitrous Oxide & $<12.6$ & $<12.6$ & $<12.6$ & 12.8 & $<12.6$ \\
\hline
\end{tabular}

(a) WHC sample identification number.

(b) PNL canister number.

(c) Replicate analysis for PNL 255 resulted in a concentration of $162 \mathrm{ppmv}$ for carbon dioxide. 


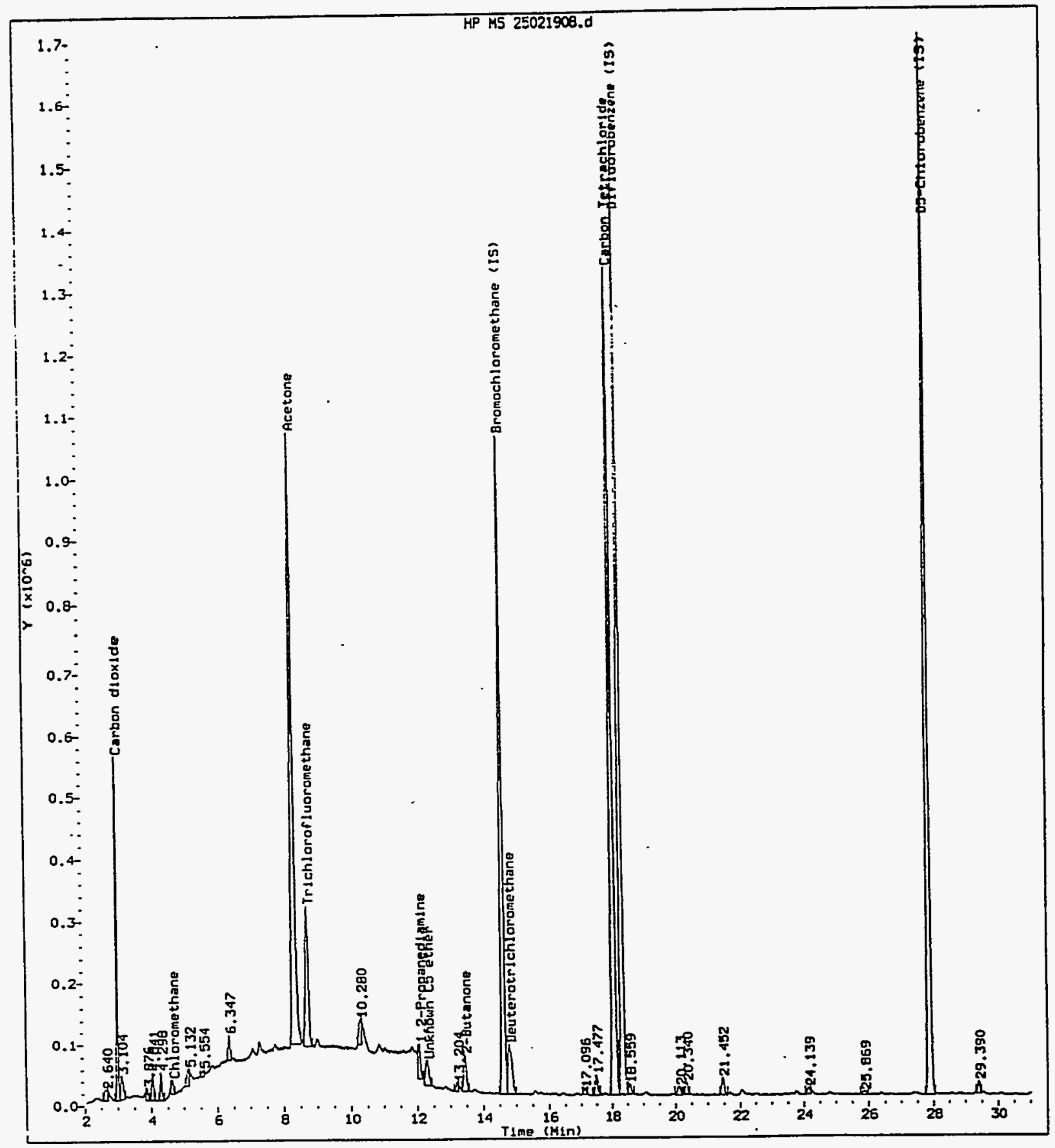

Figure 3.1a Total Ion Chromatogram (2 - $30 \mathrm{~min}$ ) for Hanford Waste Tank TX-105 SUMMA ${ }^{\text {mx }}$ Canister Sample S4087-A08.153 Collected on 12/20/94 


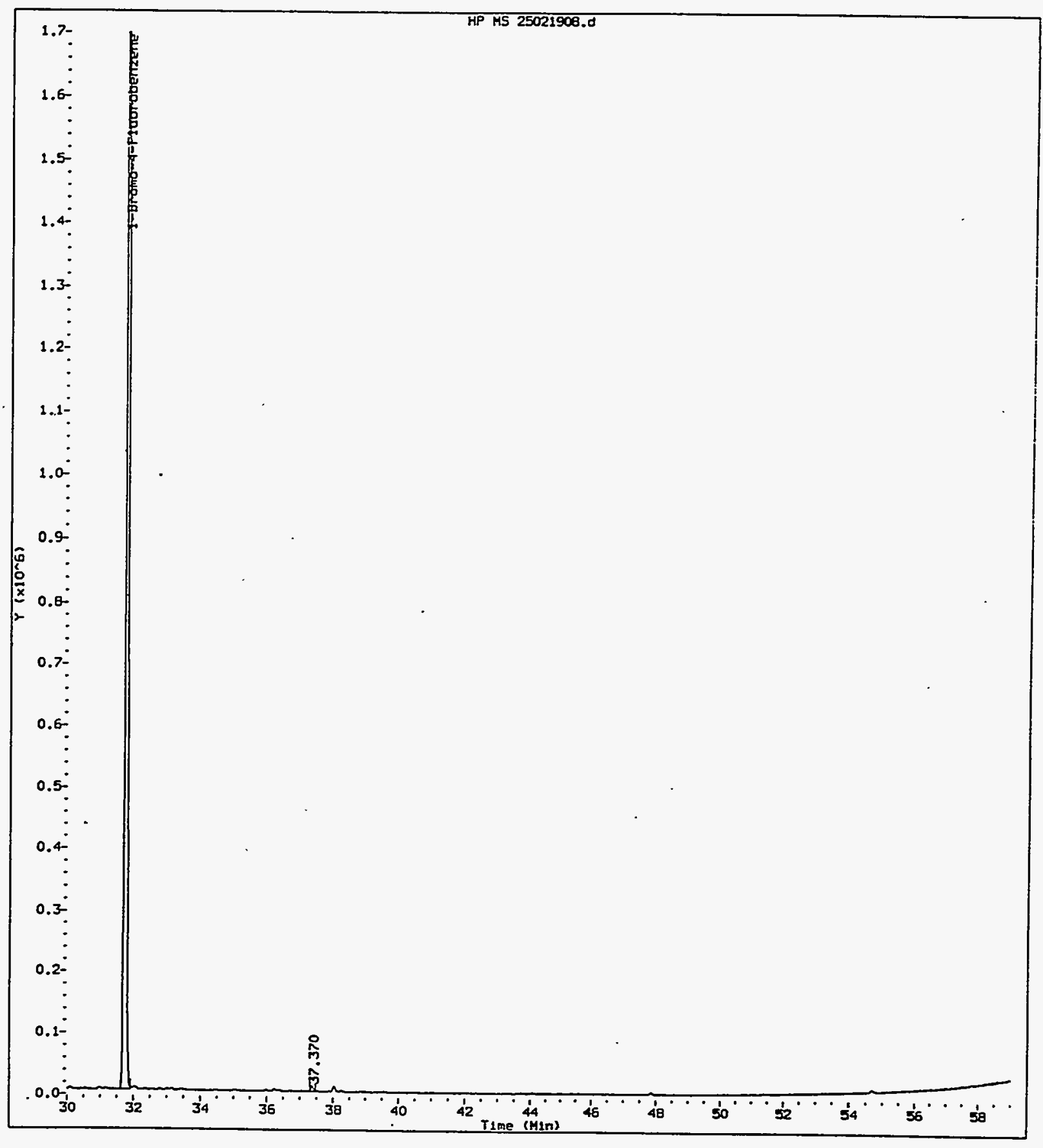

Figure 3.1b Total Ion Chromatogram ( 30 - $58 \mathrm{~min}$ ) for Hanford Waste Tank TX-105 SUMMA ${ }^{\text {Tx }}$ Canister Sample S4087-A08.153 Collected on 12/20/94 


\section{Distribution}

\section{No. of Copies}

Offsite

2 DOE/Office of Scientific and Technical Information

R. A. Jenkins

Oak Ridge National Laboratory

P.O. Box. 2008

Building 4500-5, MS 6120

Oak Ridge, Tennessee 37831-6120
No. of Copies

Onsite

2 DOE Richland Operations Office

J. M. Clark, S7-54

T. Noble, S7-54

Corps of Engineers

T. W. Gardner-Clayson, A5-19

3 Westinghouse Hanford Company

H. Babad, R2-78

D. R. Bratzel, S7-31

J. E. Meacham, S7-15

27 Pacific Northwest Laboratory

S. C. Goheen, P8-08 (20)

J. L. Huckaby, K6-55

M. W. Ligotke, P7-59

Technical Report Files (5) 